öz

Günümüz kentlerinde sanayileşme, nüfus artışı, göç, gelişmişlik düzeyi, ulusal politikalar gibi çeşitli faktörler doğrultusunda gerçekleşen yoğun, planlanmamış ve çarpık kentleşmeye bağlı pek çok sorun görülmektedir. Bu sorunların çevresel kaynaklar, kent mekanı ve kentin yaratıcı ve yürütücü unsuru insan üzerinde neden olduğu etkiler on yıllardır pek çok disiplinde tartışılmaktadır. Dolayısıyla insan ve çevre arasındaki karşılıklı ve kuvvetli etkileşim, insanın bedensel ve psikolojik sağlığını, kentsel tasarımda ele alınması kaçınılmaz konulardan biri yapmaktadır. Özellikle çevre psikolojisi alanında yer bulan insan psikolojisi ve çevre arasındaki ilişki, kentsel sorunlar konusuyla ilgili olarak ekopsikoloji yaklaşımında karşılık bulmaktadır (Rozsak, 1992). İnsan ve doğa arasında yeniden kurulacak bağın çevresel sorunların çözümündeki rolüne dikkat çeken yaklaşım, bu bağın kurulabilmesi için ise bireylerin doğal alanlarda vakit geçirmesi ile elde ettikleri ekoterapi hizmetinin gerekliliğinden bahsetmektedir. Bu gereklilik doğrultusunda bu çalışma, kentin ekoterapi hizmeti sağlayan fonksiyonları ve özelliklerinin araştırılmasını amaçlamaktadır. Bu amaçla ekopsikoloji ve ekoterapi konu başlıklarında sistematik literatür taraması gerçekleştirilmiş, ulaşılan 37 makale içerisinde terapötik mekânların türleri, özellikleri, faydaları ve terapötik aktiviteler incelenmiştir. İncelenen 4 eksen dâhilinde anahtar kelimeler halinde çekilerek gruplanan tanımlar söylem analizine tabi tutulmuştur. Belirlenen fayda, tür, özellik ve aktivitelerin mekânının niteliklerini belirleme konusundaki en önemli araçlardan olan kentsel tasarım süreçlerine sunabileceği katkılar ve dâhil olabileceği aşamalar tartışılmıştır.

\section{Abstract}

The effects of intensive and unplanned urbanization on environmental resources, urban space, and humans have been discussed in many disciplines. In this context, the interaction between human and the environment makes the physical and psychological health of the human one of the inevitable issues to be addressed in urban design. Especially in the field of environmental psychology, the relationship between human psychology and the environment finds a response in the ecopsychology approach in the context of urban problems (Rozsak, 1992). This study aims to investigate the functions and features of the urban space that provide eco-therapy service, which is indicated by the ecopsychology approach that seeks the solution of environmental problems to reconnect with nature. In this direction, a systematic

literature review was carried out within the 37 articles on the topics of eco-psychology and eco-therapy, the types, features, benefits of therapeutic areas and activities that can be carried out in these places were examined and subjected to discourse analysis. The contributions of the determined benefits, types, features, and activities to the urban design practices and the stages they can be involved in are discussed.

\title{
Birey-Doğa Illişkisinin Yeniden Kurgulanması Bağlamında Ekoterapötik Mekânlar
}

(D) Didem Kara

Ístanbul Teknik Üniversitesi Fen Bilimleri Enstitüsü, Kentsel Tasarım Yüksek Lisans Programı

(D) Gülden Oruc

İstanbul Teknik Üniversitesi, Şehir ve Bölge Planlama Bölümü

Başvuru tarihi/Received: 21.08.2020, Kabul tarihi/Final Acceptance: 20.10 .2020

\section{Giriş}

Günümüzde hızla artan nüfus, kentleşme ve sanayileşme gibi beşeri faaliyetler ve bu faaliyetlere bağlı olarak ortaya çıkan kaynak ve arazi talebinde artışa sebep olmakta, çevresel kaynakların yetersizliği, hayati ekosistemlerin yok olması, biyolojik çeşitliliğin kaybı, küresel ısınma ve kirlilik gibi çeşitli çevresel sorunlara yol açmaktadır (Singh, 2017). Kentsel alanlar, barındırdıkları nüfusa bağlı olarak endüstriyel üretim, ulaşım, fosil yakıt tüketimi, su ve diğer doğal kaynakların tüketimi ve atık üretimi gibi diğer antropojenik faaliyetlerin de yoğun olarak görüldüğü alanlardır (Singh, 2017). Bu faaliyetler, doğal alanların ve doğal kaynakların sürdürülebilirliği ile ilgili kaygilara sebep olmakla birlikte, kentlerin hâlihazırda dünya nüfusunun \%56'sını barındırması ve bu oranın yüz yıl ortasında \%70'e ulaşacağı öngörüsü (Chamie, 2020) temelinde günümüz ve gelecekteki kentsel yaşam kalitesini ve kentsel nüfusun sağl1ğını etkilemektedir.

Kentsel alanlar barındırdıkları kent sakinlerinin temel yaşam alanı ve hayatlarının büyük çoğunluğunu geçirdikleri yerlerdir. Bu durumda, kentsel alanın kalitesi ve kentleşme faaliyetinin niteliği ve işlevselliği, yaşayanların yaşam kalitesi ve sağlığını etkileyen önemli birer faktör haline gelmektedir. İşlevsel olmayan veya sağlıksız kentsel alanlar, yaşayanların yaşam kalitesini, genel refahını, sağlığını ve psikolojisini doğrudan veya dolaylı olarak olumsuz yönde etkilemektedir. Kentleşmenin ve beşeri aktivitelerin insanın gıda, $\mathrm{su}$, temiz hava gibi hayati ihtiyaçlarını karşıladığı doğal alanlar üzerinde yarattığı kirlilik (Ichimura, 2003; Jackson, 2003; Moore vd., 2003; Mutatkar, 1995) ve bu gerekli ekosistemlerin kentleşme baskısı sebebiyle kaybolmas1 (Arthur vd., 2019; Ichimura, 2003; Moore $v d$., 2003) gibi faktörler hayati ekosistem hizmetlerinin karşılanamaması sebebiyle insanı etkileyen dolaylı etkilerdendir. Doğrudan etkenler ise kentsel alandaki fiziksel niteliklere bağlı olarak oluşan fiziki çevre kontrolü sorunları (günışığ havalandirma vb.) (Flies vd., 2019; Jackson, 2003; Liu vd., 2019; Moore vd., 2003; Phillips, 1993; Weimann \& Oni, 2019) altyapı yetersizliklerine bağlı olarak oluşan kirlilik, yetersiz toplu ulaşım ve trafik sıkışıklığı, sosyal donatıların yetersizliği (Jackson, 2003; Liu vd., 2019; Weimann \& Oni, 2019), hareketsiz yaşam tarz1, sağlıksız gida arzı (Flies vd., 2019; Jackson, 2003; Kumar vd., 2019; Mutatkar, 1995; Restivo vd., 2019), yüksek nüfus yoğunluklarına bağlı olarak meydana gelen aşırı kalabalık hissi (overcrowding), güven ve mahremiyet eksikliği, yalnızlık, izolasyon, sosyal çatışmalar ve suç (Bhugra vd., 2019; Flies vd., 2019; Jackson, 2003; Qiu vd., 2019; Reichert vd., 2020; Weimann \& Oni, 2019) gibi faktörlerin sebep olduğu 
sağlık sorunları ve psikolojik rahatsızlıklardır. Tanımlanan sağlık sorunları kentsel alanda nüfus yoğunluklarına bağlı olarak yayılması kolay olan grip (Jackson, 2003), tüberküloz (Jackson, 2003; Moore vd., 2003; Mutatkar, 1995), malarya (Mutatkar, 1995; Phillips, 1993) ve zührevi hastalıklar (Mutatkar, 1995) gibi bulaşıcı hastalıklar; yaşam tarzına bağlı olarak ortaya çıkan kardio-vasküler hastal1klar (Flies vd., 2019; Jackson, 2003; Kumar vd., 2019; Restivo vd., 2019), inme, yüksek kan basinc1, diyabet, obezite (Jackson, 2003) ve oto-immün rahatsızlıklar (Flies vd., 2019); ve kentsel alandaki kirliliklere maruz kalınması sebebiyle ortaya çıkan astım (Flies vd., 2019; Jackson, 2003; Kumar vd., 2019; Moore vd., 2003; Mutatkar, 1995; Weimann \& Oni, 2019), bronşit (Jackson, 2003; Kumar vd., 2019), alerji (Flies vd., 2019) ve kanser (Jackson, 2003)) gibi rahatsızlıklardır. Psikolojik rahatsızlıklar ise stres (Bhugra vd., 2019; Jackson, 2003; Moore vd., 2003; Weimann \& Oni, 2019), uyku bozukluğu (Bhugra vd., 2019), depresyon (Jackson, 2003; Phillips, 1993; Reichert vd., 2020; Weimann \& Oni, 2019), alkolizm (Jackson, 2003), şizofreni (Flies vd., 2019; Jackson, 2003; Reichert vd., 2020), saldırganlık (Jackson, 2003), çeşitli davranış (Phillips, 1993) ve duygudurum bozukluklar1, anksiyete (Flies $v d$., 2019), kasti olarak kendine zarar verme (Moore vd., 2003) ve intihar (Arthur vd., 2019; Phillips, 1993), cinayet (Moore $v d ., 2003)$ ve suistimal (Reichert $v d$., 2020) gibi sorunlardır. Bu noktada, Şekil 1'de de görüldüğü gibi, insan kaynaklı bir aktivite olan kentleşmenin ve kentsel alanların olumsuz etkilerinin tekrar kaynağına dönerek, insanı olumsuz etkileyen birer faktör haline geldiği bir nedensellik döngüsü ile karşı karşıya kalınmaktadır.

Bu döngünün anlaşılması ile hem kentleşmenin kaynak unsuru hem de etkileneni olarak insanın çevresiyle kurduğu ilişki önem kazanmaktadır. Kaynak unsur olarak kentleşmeye sebep olan ve kentsel alanların fiziksel yapısı ve nüfus yoğunluğu ile karşı karşıya kalan insanın, doğa ile ilişkisinde bozulmalar meydana geldiği ileri sürülmektedir. Doğadan ve doğal yaşamdan uzaklaşarak kentsel yaşama adapte olan birey ise doğaya zarar veren faaliyetleri sürdürmekte bir beis görmemekte ve çevre bilincini yitirmektedir (Rozsak, 1992).

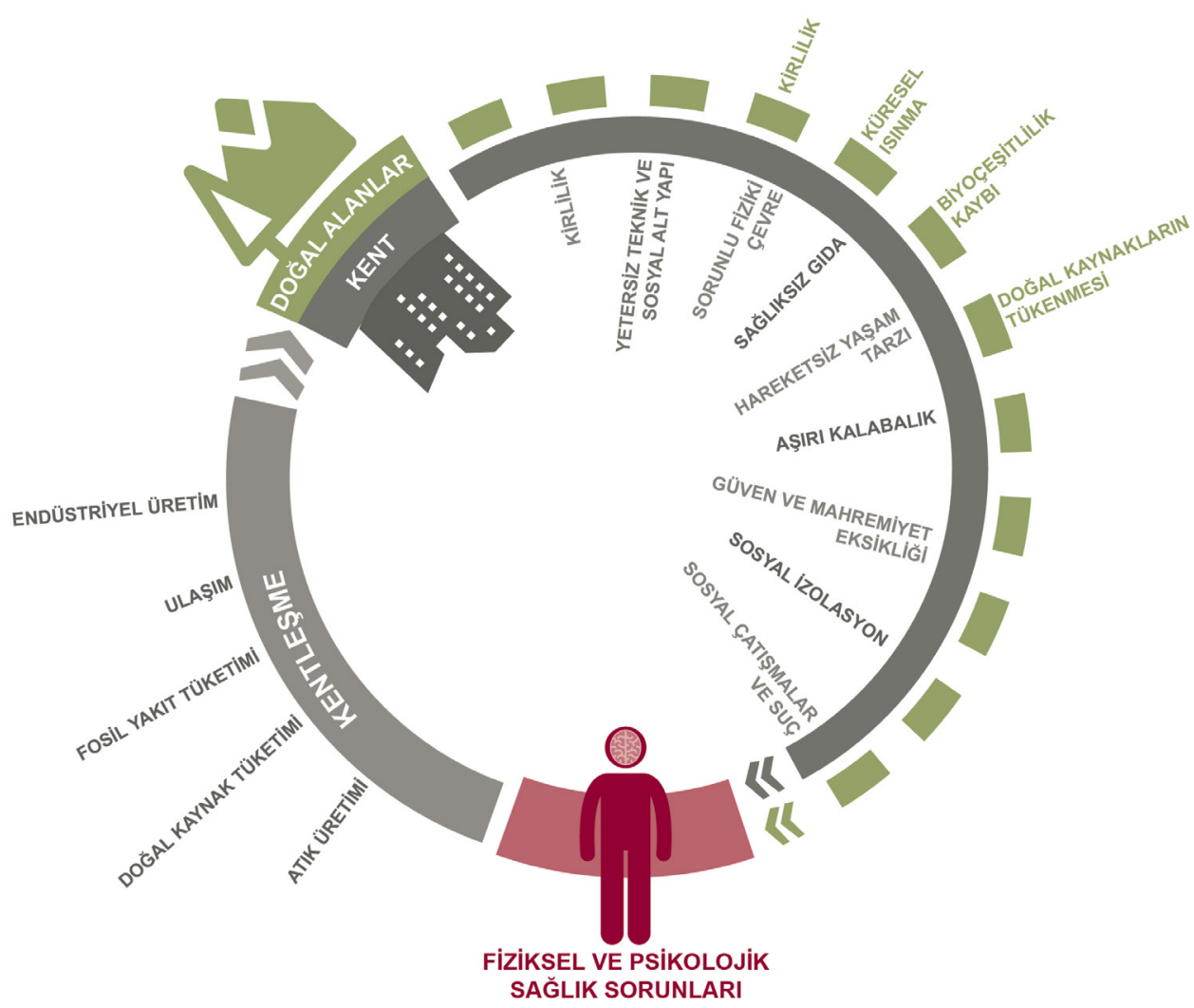

Şekil: I

Kentleşme ve insan să̆lı̆̆l arasındaki nedensellik döngüsü.

Anahtar Kelimeler: Kentsel tasarım, çevre psikolojisi, ekopsikoloji, ekoterapi, çevresel sorunlar.

Keywords: Urban design, environmental psychology, eco-psychology, eco-therapy, environmental problems.

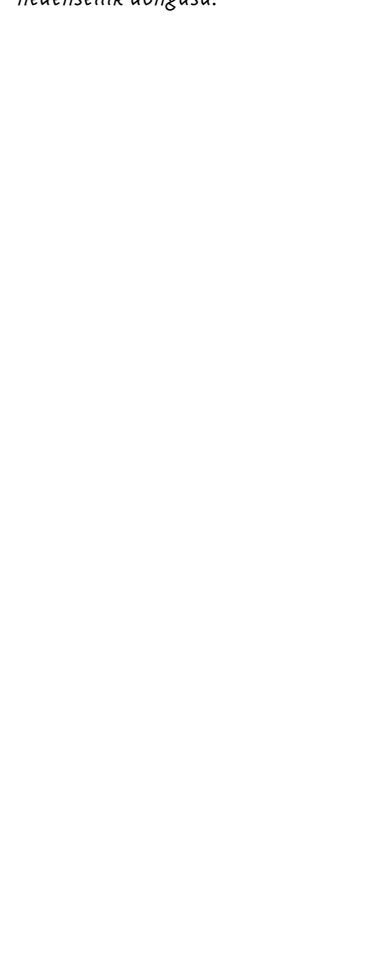


Dolayısıyla bireyin bu faaliyetlerinin ve bilincinin niteliği, toplum içerisinde sahip olduğu bilim insanı, yönetici, karar verici, üretici, tüketici ve en önemlisi dünya ekosisteminin bir parçası gibi vasıflar ve bu vasıflar ile oluşturduğu toplumların niteliği nedeniyle çevresel sorunlar konusunda önemli hale gelmektedir. Jung birey ve toplum arasındaki ilişkiyi "Maalesef çok açıktır ki, birey kendini ruhen yeniden yaratmazsa, toplum da yaratamaz, çünkü toplum kurtuluşu arayan bireylerin toplamından oluşur." şeklinde açıklamıştır (Jung, 1999). Buradaki bağlamı farklı olsa da bu bakış açısının çevresel sorunlar için de benimsenebileceği, çevresel krizin çözümü için bireyden başlayan ve toplumu şekillendiren bir dönüşümün gerekliliğinden bahsedilebilir.

Toplumu yönlendirmeleri bakımından ülke ve kent yönetimlerinin uyguladığı çevre koruma politikaları, sivil toplum kuruluşlarının yürüttüğü koruma ve bilinçlendirme çalışmaları ve şehir planlama, peyzaj mimarlığı ve mimarlık gibi çevre bilimi dallarının çevresel sorunlara ve bu sorunların ekosistemler ve insan sağlığı üzerindeki olumsuz etkilerine çözüm getirme uğraşları önem kazanmaktadır. Ekolojik, toplumsal ve ekonomik sürdürülebilirliği odak alan kent planları; doğal kaynakların etkin kullanımına yönelik akıllı büyüme yaklaşımları; ekolojik ve kültürel çevreyi bütünleşik bir sistem olarak ele alan ve sürdürülebilirliğin sistemin toptan yeniden inşası ile mümkün olduğunu gösteren rejeneratif tasarım yaklaşımları (Pedersen Zari, 2010; Reed, 2007); kentleşmenin ekosistemler üzerindeki etkilerini azaltmaya ve bu alanların rehabilite edilmesine yönelik kurgulanan biyomorfik tasarım yaklaşımlar1 (Kindel, 2019); doğal sistemlerin verimliliği örnek alınarak tasarım yapan biyomimikri yaklaşımı (Kellert, 2014); doğal alanların insan üzerindeki olumlu etkileri ve kentteki doğal alanların korunması, zarar gören doğal alanların ise restore edilmesi üzerinde temellenen biyofilik tasarım yaklaşımlar1 (Beatley, 2011) gibi kent planlamas1 ve tasarım yaklaşımları, sürdürülebilirliği ve insan sağlığı ve refahının iyileştirilmesini amaçlayan uygulamalara örnek olarak ve- rilebilir. Ancak insanın çevreye etkisi gün geçtikçe artmaya ve çevresel sorunların ekosistemler ve insan üzerindeki etkileri büyümeye devam etmektedir. Bu durumda, daha önce bahsedildiği gibi çevresel krizi bireyin doğa ile ilişkisi ve bireyin dönüşümü bazında ele alan çevre psikolojisi ve ekopsikoloji gibi sosyal bilimlerin çıktıları, özellikle kent politikaları, kent planlaması ve kentsel tasarım gibi kentsel mekanın özelliklerini belirleyen disiplinlere katk1 sunma potansiyeline sahiptir.

Hâlihazırda insan ve çevresi arasındaki etkileşimi konu alan çevre psikolojisi teorileri kentsel tasarım disiplininde çokça yer bulmakta, tasarım süreçlerine yön vermektedir. Bu doğrultuda, bu çalışmanın amacı çevresel krizin ve insanın psikolojik krizinin çözümünü insan-doğa ilișkisinin yeniden kurgulanmasında arayan ekopsikoloji (Rozsak, 1992) yaklaşımının kentsel tasarım çalışmalarına sağlayacağı katkıları araştırmak ve kentsel tasarım sürecine değerlendirilecek yeni bir perspektif kazandırmaktır. Bu amaçla bu çalışma kapsamında, ekopsikoloji ve ekoterapi çalışmalarının insan-doğa ilişkisinin yeniden kurulmasına olanak sağlayan mekânlar olarak gösterdiği doğal alanların ve kent içerisinde doğal öğeleri barındırmalarına istinaden kentsel yeşil alanların, bu çalışmalar tarafindan ortaya konan mekânsal nitelikleri incelenmiş; tespit edilen mekânsal özelliklerin insan ve çevresi arasındaki ilişkiyi şekillendirmesi bakımından önemli bir araç olan kentsel tasarım süreçlerine sağlayabileceği katkılar değerlendirilmiştir. Bu bağlamda bu çalışma, mevzubahis sorunların çözümünü insan ve mekân arasındaki etkileşimi değerlendirerek arayan ekopsikoloji ve ekoterapi yaklaşımlarının tanımladığı terapötik mekanları, bu etkileşimin niteliğini etkileyecek mekânsal özellikleri tasarım sürecine entegre edilmesi hususunda belirleyici bir kaynak olarak ele almaktadır.

\section{2. Çevre Psikolojisi, Ekopsikoloji ve Ekoterapi}

Binlerce yıldır insan ve çevresi arasında kurulan güçlü bağ, temel yaşamsal ihtiyaçların karşılanması açısından değerlendi- 
rilmesinin yanında, çevre ve insan sağlığ arasındaki ilişki sebebiyle farklı bakış açılarıyla ele alınması gereken bir konudur. Jackson'a (2003) göre modern toplum, insanların ve kültürün doğal çevrenin bileşenleri olduğunun ve insan sağllğıının ayrılmaz bir şekilde çevresel koşullarla bağlantılı olduğunun farkındadır. Bu konuyu kapsayan çeşitli disiplinlerin arasında, insan ve çevre arasındaki ilişkinin insan deneyimleri, davranışı ve sağlığı üzerindeki etkisini inceleyen çevre psikolojisi öne çıkmaktadır. Psikoloji biliminin bir alt dalı olan çevre psikolojisi, 1960'lardan bu yana kentsel alanın fiziksel ve sosyal etkilerinden doğal alanların insan psikolojisi üzerindeki etkilerine kadar geniş bir yelpazede insan ve çevresi arasındaki çift yönlü ilişkiyi incelemektedir.

Çevresel sorunlardaki artış ve bu sorunlarda insanın rolü hakkında tartışmaların gelişmesi nedeniyle çevre sorunlarına karşı insan davranışını ve bilincini değiştirmenin yollarını arayan çevre psikolojisinin, sürdürülebilirlik tartışmalarının alandaki gelişmelerde önemli bir rol oynaması sebebiyle 'sürdürülebilirlik psikolojisi' olarak geliştiği iddia edilmektedir (Steg vd., 2012). Bu noktada ekopsikoloji, çevre bilincinin geliştirilmesi ve çevresel sorunlara karşı insan davranışlarının değiştirilmesi bakımından önemli bir çevre psikolojisi alt alanı olarak karşımıza çıkmaktadır.

'Ekopsikoloji' terimi ilk kez 1992 yılında Theodore Roszak tarafindan kullanılmıştır. 'The Voice of Earth' (Dünyanin Sesi) adlı kitabında Roszak (1992), insan faaliyetlerinin ve ekonomik sistemin nasıl değiştiğini tartışmış, bu değişen faaliyetlerin ve ekonomik düzenin ekosistemler üzerindeki olumsuz etkilerinden bahsetmiştir. İnsanın kentleşme nedeniyle doğadan ve diğer insanlardan koptuğundan bahseden Roszak, bu kopukluğun hem insanın çevre üzerindeki olumsuz etkisini artırdığını hem de psikolojik sorunlarını derinleştirdiğini belirtmektedir. $\mathrm{Bu}$ sorunların çözümü için ise kolektif bir ekopsikolojinin yaratılması gerekliliğinden bahsedilmektedir (Rozsak, 1992).

Ekopsikolojinin çalışma alanı, ekolojik kriz ile insanın manevi veya psikolojik kri- zi arasındaki ilişkidir. Bozulmuş doğa-insan ilişkisi bağlamında çevre sorunlarındaki insan psikolojisi ve toplumun köklerini incelemektedir. Dolayısıyla kavram, çevre psikolojisinden konusu ve araştırma yöntemleriyle ayrılmaktadır. Ekopsikoloji felsefe, maneviyat ve psikoterapi ile ilgilenirken, çevre psikolojisi nicel araştırmalara ve bilişsel-davranışçı psikolojiye bağlıdır (Scull, 2008).

İnsan ve çevre arasındaki ilişkiye yaklaşma anlamında ekopsikolojinin teori ve pratikteki yeri Scull tarafından 'ekopsikoloji deneyimseldir ve doğa ile temas halinde birçok şey öğrenilebilir; ekopsikoloji spekülatif, felsefi ve teoriktir ve doğa-insan ilişkisinin yeni bir dil ve modelle yeniden yapılandırılabileceği temeli hazırlamaktadır; ve son olarak çevre aktivizmi ve ekoterapi gibi uygulamalar vasitasıla çevrenin korunmasında ve insan psikolojik sorunlarının çözümlenmesinde rol oynayabilir' şeklinde açıklanmıştır (2008).

Yapılan tanımlamalara bakılarak, ekopsikolojinin ve uygulama aracı ekoterapinin şuana kadar bahsedilen sorunlara bir çözüm önerdiği söylenebilir. Ekopsikoloji yaklaşımının bir uygulama aracı olarak ekoterapi, Clinebell (1996) tarafindan 'dünya ile sağlıklı bir ilişki ile iyileşme ve büyüme' olarak tanımlanmıştır. Clinebell (1996), türümüzün devamlılı̆g i için hayati ekosistemler üzerindeki yıkıcı etkisi nedeniyle dünyanın ekolojik bozulmasını tüm zamanların en derin sağlık sorunu olarak tanımlamakta; yaşam tarzlarımız hakkında bir farkındalık geliştiren soruna da bir çözüm önerisi ortaya atmaktadır. Clinebell (1996) ekoterapötik çalışmaların temelini üç adet ortak etkileşimli ekolojik döngüden aldığından bahsetmektedir:

- Onama (Inreach): doğanın ve dünyanın iyileştirici varlığı ile içsel kabulleniş ve beslenme.

- İdrak (Upreach): İnsandan öte (more than human) deneyimi ile kendini doğaya tekrar yerleştirme (relocation).

- Aktarma (Outreach): diğer insanlarla birlikte doğa için iyi bir şeyler yapma. 
Ekoterapi temelde, doğada açık hava etkinlikleri yaparak zihinsel ve fiziksel sağlığı geliştirmeyi amaçlayan çeșitli tedavi programlarına verilen addır. Doğa ile bu şekilde kurulan bağlantının insan sağlığı üzerinde birçok olumlu etkisi olabilmektedir. Ekoterapi, parklar, bahçeler, çiftlikler ve ormanlık alanlar gibi kırsal ve kentsel ortamlarda gerçekleştirilebilir (Wheeling, 1993). Bu alanlarda gerçekleştirilecek olan ekoterapötik aktiviteler sirasında bir uzmandan destek alınabileceği gibi, kişi kendi başına bu alanlarda vakit geçirerek de doğadan terapi hizmeti alabilmektedir. ekoterapötik faaliyetlerin türleri incelendiğinde ise iki ana grubun ortaya çıktığı görülmektedir. Bunlar:

- Doğada çalışmak: koruma projeleri, bahçecilik, tarım vb.

- Doğayı deneyimlemek: doğal alanlarda yürüyüss, bisiklet sürmek, manzara izlemek vb. (Wheeling, 1993).

Özetlemek gerekirse, insanın doğada olmas1 ve ekosistemdeki yerini anlaması çevre krizi ve insanın psikolojik krizi ile ilgili sorunları çözmede önemli bir adımdır. Ekoterapi, insanın kendi doğasını tanımasını, doğa ile iç içe bir yaşam biçiminin kentsel alanda günlük hayatın bir parçası haline getirilmesini ve insanın yalnızca bir parçası olduğu dünya ekosistemine saygılı olmasını amaçlamaktadır. Bu bağlamda yaklaşım, çevre bilincinin gelişmesi ve çevre sorunlarının kaynağı olan 'bireyin' dönüşümünü hedef almasıyla bireyden başlayan bir çözümün sağlanması bakımından potansiyele sahiptir.

\section{Kentsel Mekan ve Ekoterapi İlişkisi}

Daha önce de bahsedildiği gibi kente insanın temel ihtiyaçlarını karşıladığı fonksiyonları ve bu fonksiyonlar arasındaki bağlantıları içeren ana yaşam alanı olarak bakıldığında, nitelikleri ve sunduğu imkânların insanın yaşam biçimi, sağlığı ve psikolojisi üzerindeki etkileri kaçınılmaz olmaktadır. Dolayısıyla mekânın olumsuz nitelikleri ve eksiklerine bağlı olarak ortaya çıkan olumsuz etkilerden biri olan doğadan kopma ise kentleşme biçimini ve bireylerin kent içerisindeki yaşam tarzını etkilemekte; hem kentsel mekânda hem doğal kaynaklar üzerinde pek çok olumsuz etki yaratmaktadır. Bağlı olarak doğal alanların ve elemanların çarpık kentleşme nedeniyle az bulunur hale geldiği kentlerde doğadan kopuş artmakta, bu döngü bu haliyle devam etmektedir.

$\mathrm{Bu}$ açıdan, kentlerin doğal öğeler bakımından zengin yeşil ve mavi altyapı alanlarını içerisinde barındıracak nitelikte gelişmesi gerekliliği önem kazanmaktadır. Kent sistemi içerisinde biyolojik çeşitliliğin ve su ve karbon gibi doğal döngülerin sürdürülmesi, sert zemin etkilerinin azaltılması, mikro klimanın düzenlenmesi, kirliliğin azaltılması ve kentsel 1sı adas1 etkisinin azaltılması gibi kentsel mekanın fiziki kalitesini artırıcı pek çok faydasının yanında yeşil ve mavi altyapı, kentlinin rekreasyon ihtiyaçları, yaşanabilir ve yürünebilir çevrelerin yaratılması, daha aktif bir yaşam tarzının desteklenmesi bakımından da önem arz etmektedir. Bu önem doğrultusunda yeşil alanlar, geçmişten günümüze çevre mühendisliği, peyzaj mimarlığı, kent planlaması, kentsel tasarım ve mimari gibi pek çok çevre biliminin de kentsel sorunların çözümü amacıyla ele aldığı önemli bir araştırma alanı haline gelmiştir.

Tüm bunlara ek olarak, çevresel krizi bireyin dönüşümü ve doğayla yeniden ilişki kurmasi temelinde ele alan ekopsikoloji yaklaşımında da doğal ve doğal öğeleri barındıran alanların bu husustaki öneminin öne çıktığı görülmektedir. Dolayısıyla, yeşil alanların kent içerisindeki varlığı, dağılımı ve niteliklerini kentsel ve rekreatif faydalar doğrultusunda değerlendiren kentsel planlama ve tasarım disiplinlerinin, ekopsikoloji perspektifinin sunduğu yararları da ele almasıyla kentlinin kentsel yeşil alanlardan sağladığı faydaların artacağı söylenebilir. Böylece kentsel yeşil alanlar, kentsel ve rekreatif faydalar doğrultusunda gereken büyüklükte arz edilmesi gereken birer plan lejantı olmaktan çıkıp, kentlinin refahına, sağlığına, psikolojisine ve doğa ile olan ilişkisinin yeniden kurgulanması ile çevresel sorunların azaltılmasına katkı sağlar hale gelebilecektir. Bu bağlamda ekopsikoloji ve ekoterapi disiplinlerinin sunduğu insan-mekân ilişkisi temelinde ele 
alınan terapötik mekânlara dair çalışmalar, bu çalışma kapsamında kentsel planlama ve tasarım disiplinlerine tasarım sürecinde ele alınacak kriterleri sağlamaları nedeniyle birer belirleyici olarak değerlendirilmektedir.

Kentsel yeşil alanların birey-doğa ilişkisinin yeniden kurgulandığı mekânlar olarak ele alınabilmesi ve tasarlanabilmesi için, ekopsikoloji ve ekoterapi yaklaşımlarının tariflediği 'terapötik' mekânların ve bu mekânların bu ilişkiye katkı sağlayan özelliklerinin araştırılması gerekmektedir. Terapötik mekânların araştırılması amacıyla ekopsikoloji ve ekoterapi literatüründe mekânın özelliklerini konu alan çalışmaların incelenmesi hedeflenmiştir. Scopus veritabanında gerçekleştirilen incelemede 'Ecopsychology' anahtar kelimesi ile yapilan tarama sonucunda 1995-2020 yilları arasında yayınlanmış 249 makaleye, 'Ecotherapy' anahtar kelimesi ile yapilan tarama sonucunda ise 2005-2020 yilları arasında yayınlanmış 57 makaleye ulaşılmıştır. $\mathrm{Bu}$ makaleler 'psikoloji', 'sosyal bilimler' ve 'çevre bilimleri' alanlarında çalışılmış olmaları ve mekânla kurdukları ilişki doğrultusunda filtrelenerek, ekopsikoloji alanından 5 ve ekoterapi alanından 19 makaleye indirgenmiştir. Geriye kalan 24 makalenin kaynakçaları taranarak, ilişkili bir çalışma alanı olan restoratif çevreler (restorative environments) (Ulrich, 1983) alanından 13 makale çalışmaya eklenmiş, toplam 37 kaynak detaylı bir şekilde incelenmiştir.

Yapılan inceleme terapötik çevrelerin faydaları, türleri, özellikleri ve terapötik aktiviteler olmak üzere 4 ana eksen üzerinde gerçekleştirilmiştir. Bu eksenler doğrultusunda makalelerin içinden fayda, tür, özellik ve aktiviteler anahtar kelimeler halinde çekilmiş, söylem analizi yard1miyla birbirleri ile olan ilişki ve benzerlikleri bakımından alt gruplara ayrılmıştır. Belirlenen alt gruplar ekopsikoloji yaklaşımında tanımlanan özelliklerin kentsel tasarım sürecine entegre olacağı aşama ve yerin belirlenmesinde yönlendirici kabul edilmiştir.

\section{Ekoterapötik Çevreler}

\subsection{Ekoterapötik Çevrelerin Faydaları}

Doğal ve yeşil alanlar, ekopsikoloji ve restorasyon çalışmalarında insan sağlığı ve refahına sağladıkları faydalar doğrultusunda değerlendirilmektedir. Bu çalışmalarda sözü edilen faydalar bu bağlamda insan üzerindeki etkileri doğrultusunda tespit edilip gruplanmıştır. Doğal ve yeşil alanlardan elde edilen faydalar sağlık ve refaha katkıları, zihinsel ve duygusal faydalar ve kişinin kendini yerleştirdiği konum ve alg1 ile ilgili faydalardır (Şekil 2).

Genel sağlık ve refah faydaları arasında uyku kalitesinde artış, artan bağışıklık tepkisi, ameliyat veya yaralanmalardan daha hızlı iyileşme, doğrudan insan sağlığı ve yaşam uzunluğu ile ilişkili olan telomer uzunluğunda artış ve genel olarak artan refah sayılabilir (Tablo 1). Doğada vakit geçirmek ayrıca ADD / DEHB, yüksek kan basınc1, yüksek nabız, baş ağrısı ve genel ağrılar ve obezite gibi sağlık sorunlarında da iyileşmeye yardımcı olmaktadır (Tablo 1). Yeşil alanlar ile temas sonrası dikkat, odak, yaratıcılık, üretkenlik, problem çözme yeteneği ve hafiza gibi zihinsel süreçlerde iyileşme görülmektedir (Tablo 1). Zihinsel faydaların yanında doğal alanlarda geçirilen vakit sakinlik, deşarj, rahatlık, restorasyon, daha iyi bir ruh hali, mutluluk, zevk ve eğlence gibi duygularda artışa; saldırganlık, öfke, kaygı, uyarılma, bunama, depresyon, zihinsel yorgunluk, yılgınlık, korku, kaybolmuşluk hissi ve stres düzeyinde ise azalmaya yol açmaktadır (Tablo 1).

Son olarak, çeşitli çalışmalar doğada vakit geçirmenin bireylerin kendi kendini yerleştirdiği konumda ve benlik algısında değişikliğe ve gelişmeye sebep olduğunu belirtmektedir. Bu değişiklik ve gelişme-
Şekil: 2

Ekoterapötik f̧eurelerin faydaları.

Ekoterapötik Çevrelerin Faydaları

Sağlık ve Refahta İyileşme
Zihinsel ve Duygusal Faydalar
Konum ve Benlik Algısında İyileşme 
Tablo: I

Ekoterapötik çevrelerin sağlık ve refah'a zihinsel ve duygusal süreçlere faydaları.

\begin{tabular}{|c|c|c|c|}
\hline \multicolumn{2}{|r|}{ Faydalar } & \multirow{2}{*}{ Orijinal Adı } & \multirow{2}{*}{ Abdelaal \& Soebarto, 2019} \\
\hline \multirow{11}{*}{$\begin{array}{l}\text { Sağlık ve } \\
\text { Refah }\end{array}$} & Uyku kalitesinin iyileşmesi & & \\
\hline & Bağışıklık tepkisinin artması & $\begin{array}{l}\text { Increased immune } \\
\text { response }\end{array}$ & Ibes vd., 2018 \\
\hline & $\begin{array}{l}\text { Ameliyat ve yaralanmalardan } \\
\text { daha hızlı iyileşme }\end{array}$ & Recovery and recuperation & $\begin{array}{l}\text { Abdelaal \& Soebarto, 2019; Burls, 2007; Phelps vd., } \\
\text { 2015; Schebella vd., 2017; Summers \& Vivian, 2018; } \\
\text { Szczygiel, 2003; Wilson vd., 2009, } 2010\end{array}$ \\
\hline & Telomer uzunluğunun arması & Increased telomere lenght & Grassini vd., 2019 \\
\hline & Genel sıhhatin artması & Well-being & Pálsdóttir vd., 2015; Summers \& Vivian, 2018) \\
\hline & ADD/DEHB azalması & $A D D / A D H D$ & $\begin{array}{l}\text { Greenleaf vd., 2014; Stevens, 2010; Summers \& } \\
\text { Vivian, } 2018\end{array}$ \\
\hline & Yüksek kan basıncının düşmesi & $\begin{array}{l}\text { Decrease in high blood } \\
\text { pressure }\end{array}$ & $\begin{array}{l}\text { Ibes vd., 2018; Summers \& Vivian, 2018; Wilson vd., } \\
2009\end{array}$ \\
\hline & Yüksek nabzın düşmesi & $\begin{array}{l}\text { Decrease in high hearth } \\
\text { reate }\end{array}$ & Summers \& Vivian, 2018 \\
\hline & Baş ağrıarının azalması & Decrease in headaches & Abdelaal \& Soebarto, 2019 \\
\hline & Genel ağriların azalması & Decrease in pain & Phelps vd., 2015; Schebella vd., 2017 \\
\hline & Obezitenin azalması & Obesity & Summers \& Vivian, 2018 \\
\hline \multirow{24}{*}{$\begin{array}{l}\text { Zhinsel ve } \\
\text { Duygusal }\end{array}$} & Dikkatin iyileşmesi & Better attention & $\begin{array}{l}\text { Clatworthy vd., 2013; Greenleaf vd., 2014; Ibes vd., } \\
\text { 2018; Kamitsis \& Simmonds, 2017; Pasanen vd., } \\
\text { 2018; Phelps vd., 2015; Wilson vd., 2009, } 2010\end{array}$ \\
\hline & Odaklanmanın artması & Better concentration & $\begin{array}{l}\text { Greenleaf vd., 2014; Pedretti-Burls, 2007; Reese \& } \\
\text { Lewis, 2019; Schebella vd., } 2017\end{array}$ \\
\hline & $\begin{array}{l}\text { Yaratıc lığın artması } \\
\text { Üretkenliğin artması }\end{array}$ & $\begin{array}{l}\text { Increased creativity } \\
\text { Increased productivity }\end{array}$ & $\begin{array}{l}\text { Summers \& Vivian, 2018; Wang \& MacMillan, } 2013 \\
\text { Burls, } 2007\end{array}$ \\
\hline & $\begin{array}{l}\text { Problem çözme becerisinin } \\
\text { artması }\end{array}$ & $\begin{array}{l}\text { Better problem solving } \\
\text { ability }\end{array}$ & Clatworthy vd., 2013 \\
\hline & Hafızanın güçlenmesi & Better memory & Clatworthy vd., 2013; Summers \& Vivian, 2018 \\
\hline & Sakinleşme & Calming & Burls, 2007 \\
\hline & Deşarj olma & Recharging & Wilson vd., 2009 \\
\hline & Rahatlama & Relaxing/Relief & $\begin{array}{l}\text { Burls, 2007; Grassini vd., 2019; Schebella vd., 2017; } \\
\text { Stevens, 2010; Wilson vd., 2009, } 2010\end{array}$ \\
\hline & Restorasyon & Restoration & Summers \& Vivian, 2018 \\
\hline & Daha iyi bir ruh hali & Better mood & $\begin{array}{l}\text { Abdelaal \& Soebarto, 2019; Clatworthy vd., 2013; } \\
\text { Grassini vd., 2019; Greenleaf vd., 2014; Schebella vd., } \\
\text { 2017; Summers \& Vivian, } 2018\end{array}$ \\
\hline & Mutluluğun artması & Happiness & Reese \& Lewis, 2019; Schebella vd., 2017) \\
\hline & Zevk & Pleasure & Burls, 2007 \\
\hline & Eğlence & Joy & Stevens, 2010 \\
\hline & Saldırganlığın azalması & Aggression & $\begin{array}{l}\text { Summers \& Vivian, 2018; Wilson vd., 2010; Wolsko \& } \\
\text { Hoyt, } 2012\end{array}$ \\
\hline & Öfkenin azalması & Anger & Ibes vd., 2018; Wilson vd., 2009 \\
\hline & Kaygının azalması & Anxiety & $\begin{array}{l}\text { Grassini vd., 2019; Kamitsis \& Simmonds, 2017; } \\
\text { Reese \& Lewis, 2019; Schebella vd., 2017; Summers } \\
\text { \& Vivian, 2018; Wilson vd., 2009, 2010; Wolsko \& } \\
\text { Hoyt, } 2012\end{array}$ \\
\hline & Uyarımanın azalması & Arousal & Grassini vd., 2019 \\
\hline & Bunamanın iyileşmesi & Dementia & Summers \& Vivian, 2018 \\
\hline & Depresyonun azalması & Depression & $\begin{array}{l}\text { Clatworthy vd., 2013; Kamitsis \& Simmonds, 2017; } \\
\text { Pasanen vd., 2018; Sackett, 2010; Wilson vd., 2009, } \\
\text { 2010; Wolsko \& Hoyt, } 2012\end{array}$ \\
\hline & Zhinsel yorgunluğun azalması & Mental fatigue & Wilson vd., 2010 \\
\hline & Yılgınlığın azalması & Frustration & Schebella vd., 2017; Summers \& Vivian, 2018 \\
\hline & Korkunun azalması & Fear & Wilson vd, 2009 \\
\hline & Koybolmuşluk hissinin azalması & Sense of loss & Wang \& MacMillan, 2013 \\
\hline & Stresin azalması & Stress & $\begin{array}{l}\text { Abdelaal \& Soebarto, 2019; Burls, 2007; Clatworthy } \\
\text { vd., 2013; Grassini vd., 2019; Greenleaf vd., 2014; } \\
\text { Kamitsis \& Simmonds, 2017; Pálsdóttir vd., 2015; } \\
\text { Pasanen vd., 2018; Phelps vd., 2015; Reese \& Lewis, } \\
\text { 2019; Schebella vd., 2017; Summers \& Vivian, 2018; } \\
\text { Wilson vd., 2009; Wolsko \& Hoyt, } 2012\end{array}$ \\
\hline
\end{tabular}

ler ise beden imajı ve sağlığı algısında iyileşme, zihinsel canlılık, dengelilik, normalite, uyumluluk, doğaya bağlılık, zihin-beden-ruh bağl1lığı ve sosyal bağlılık, sosyal etkileşim, sosyal beceriler, yaşam memnuniyeti, öz disiplin, öz saygı, kendini ifade etme ve kendini ilişkilendirmede artış şeklinde görülmektedir (Tablo 2).
Bahsedilen faydalardan anlaşıldığı üzere, doğal alanlarda vakit geçirmek bireylerin zihinsel ve bedensel sağllğında iyileşmeye yardımcı olabilmektedir. Ekoterapötik alanlardan sağlanan faydaların ise kentsel sorunlara bağlı olarak meydana gelen bedensel ve zihinsel sağlık sorunlarının çoğu ile örtüştüğü görülmektedir. Daha 


\begin{tabular}{|c|c|c|c|}
\hline \multicolumn{2}{|r|}{ Faydalar } & Orijinal Adı & Kaynak \\
\hline \multirow{16}{*}{$\begin{array}{l}\text { Konum ve } \\
\text { Benlik Algısı }\end{array}$} & Beden imajında iyileşme & Better body image & Reese \& Lewis, 2019 \\
\hline & Sağlık algısında iyileşme & Better perception of health & Stevens, 2010 \\
\hline & Zihinsel canlillk & Mental vitality & Reese \& Lewis, 2019 \\
\hline & Dengelilik & Feeling of well-balanced & Abdelaal \& Soebarto, 2019 \\
\hline & Normalite & Normalcy & Abdelaal \& Soebarto, 2019 \\
\hline & Uyumluluk & Compatibility & Clatworthy vd., 2013 \\
\hline & Doğaya bağlıık & $\begin{array}{l}\text { Connectedness to the } \\
\text { nature }\end{array}$ & Clatworthy vd., 2013; Schebella vd., 2017 \\
\hline & $\begin{array}{l}\text { Zihin-beden-ruh bağlantısında } \\
\text { iyileşme }\end{array}$ & Mind-body-spirit connection & Wang \& MacMillan, 2013 \\
\hline & Sosyal bağlığın artması & $\begin{array}{l}\text { Increased social } \\
\text { connection }\end{array}$ & Stevens, 2010 \\
\hline & Sosyal etkileşimin artması & Increased social interaction & Wang \& MacMillan, 2013 \\
\hline & Sosyal becerilerde iyileşme & Better social skills & Clatworthy vd., 2013; Wilson vd., 2009, 2010 \\
\hline & Yaşam memnuniyetinin artması & Increased life satisfaction & Summers \& Vivian, 2018 \\
\hline & Öz disiplinin iyileşmesi & Better self-discipline & Wilson vd., 2010; Wolsko \& Hoyt, 2012 \\
\hline & Öz saygının gelişmesi & Better self-esteem & $\begin{array}{l}\text { Clatworthy vd., 2013; Greenleaf vd., 2014; Kamitsis \& } \\
\text { Simmonds, 2017; Sackett, 2010; Schebella vd., 2017; } \\
\text { Stevens, 2010; Wang \& MacMillan, 2013; Wilson vd., } \\
2010\end{array}$ \\
\hline & $\begin{array}{l}\text { Kendini ifade etme becerilerinde } \\
\text { iyileşme }\end{array}$ & Better-self expression & Wang \& MacMillan, 2013 \\
\hline & Kendini ilişkilendirme & Self-relatedness & Stevens, 2010 \\
\hline
\end{tabular}

önce de belirtildiği gibi, bütün bir sistem ve bileşenleri olarak değerlendirildiğinde, insanlar dünya ekosisteminin en önemli parçalarından biridir. Sistemin işlerliğindeki etkisi sebebiyle her bireyin sağlığ 1 ve refahı sistemin sağlıklı bir şekilde sürdürülebilmesi anlamında önem arz etmektedir. Ekopsikoloji yaklaşımında sıkça söz edildiği üzere, kendini yer aldığı ekosistem içerisine ve topluluğa yeniden yerleştirme, bireysel algıda ve yaşam memnuniyetinde iyileşme gibi olumlu etkilerin, çevreye karş1 duyarlılığa katkı sağlaması ve tüketim alışkanlıklarını değiştirmesi bakımından çevresel krizin çözümünde önemli rol oynaması, bireylerin yaşamının büyük kısmını sürdürdüğü kentin bu değişim sürecine elverişli olmasına bağlıdır. $\mathrm{Bu}$ noktada, doğal alanların bireylerin sağlığ ve zihinsel süreçlerindeki olumlu etkisinin anlaşılması, kentsel yeşil alanların rekreatif faydalarıyla ele alınmalarının yanında, en başta tartışılan kentlerin olumsuz niteliklerine bağlı olarak ortaya çıkan bedensel ve zihinsel sağlık sorunlarının azaltılmasına yönelik mekânsal tasarım ve planların yapılmasına katkı sağlayacaktır.

\subsection{Ekoterapötik Çevrelerin Türleri}

Terapötik çevrelerin türleri incelenirken, teorik çalışmaların ekoterapötik ortamları genel olarak ekoterapi ve restorasyona hizmet eden doğal alanlar olarak ele aldığı, ampirik çalışmaların ise farklı terapötik çevrelerin sunduğu ekoterapi veya restorasyonun etkilerini ve miktarını incelediği görülmüştür. İnceleme sonucunda, ekoterapötik ortamların konumlarına göre kentin dişında, çeperinde ve içinde olmak üzere 3 ana grupta toplandığı görülmektedir (Şekil 3).

Kent dişında yer alan terapötik alanlar genel olarak doğal alanlar, doğal yeşil alanlar ve doğal peyzajlar olarak tanımlanmış, lık ve sulak alanlar, vahşi yaşam alanları ve parkları, ormanlar, ulusal ormanlar ve korular olarak belirtilmiştir (Tablo 3). Kent detaylı olarak ise, tepeler ve dağlar, batak-

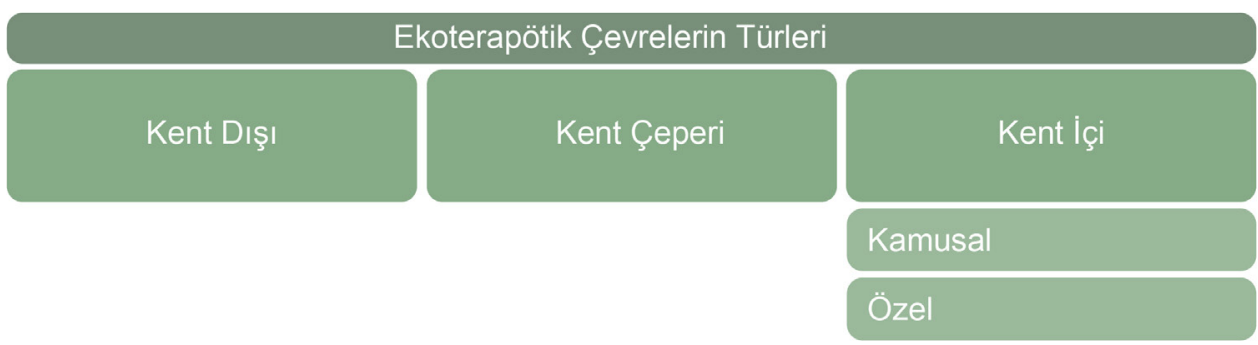

Tablo: 2

Ekoterapötik f̧eurelerin konum ve benlik algisina etkileri. 
Tablo: 3

Ekoterapötik f̧eurelerin kent dışında, kent ceperinde ve kent içinde yer alan türleri.

\begin{tabular}{|c|c|c|c|}
\hline & Türler & Orijinal Adı & Kaynak \\
\hline \multirow{10}{*}{$\begin{array}{l}\text { Kent } \\
\text { Dişı }\end{array}$} & Doğal alanlar & Natural areas/spaces & Barnes vd., 2019; Burls, 2007 \\
\hline & Doğal yeşil alanlar & Natural greenery & Pálsdóttir vd., 2015 \\
\hline & Doğal peyzajlar & Natural landscapes & Jordan \& Marshall, 2010 \\
\hline & Plajlar & Beaches & Greenleaf vd., 2014; Summers \& Vivian, 2018 \\
\hline & Tepeler ve dağlar & Foothills and mountains & Greenleaf vd., 2014; Jordan \& Marshall, 2010 \\
\hline & Bataklık ve sulak alanlar & Wetlands & Pedersen vd., 2019 \\
\hline & Vahşi yaşam alanları ve parkları & Wilderness areas/parks & $\begin{array}{l}\text { Barnes vd., 2019; Burls, 2007; Cole \& Hall, 2010; } \\
\text { Hartig vd., 2003; Sackett, 2010; Summers \& Vivian, } \\
2018\end{array}$ \\
\hline & Ormanlar & Forests & $\begin{array}{l}\text { Davis \& Atkins, 2009; Ibes vd., 2018; Juan vd., 2017; } \\
\text { Pálsdóttir vd., 2015; Pasanen vd., 2018; Summers \& } \\
\text { Vivian, 2018; Wilson vd., } 2009\end{array}$ \\
\hline & Ulusal Ormanlar & National forests & Reese \& Lewis, 2019 \\
\hline & Korular & Woodlands & Jordan \& Marshall, 2010 \\
\hline \multirow{4}{*}{$\begin{array}{l}\text { Kent } \\
\text { Çeperi }\end{array}$} & Çiftlikler & Farms & Pálsdóttir vd., 2015 \\
\hline & Çok fonksiyonlu tarım alanları & $\begin{array}{l}\text { Multifunctional agricultural } \\
\text { areas }\end{array}$ & Pálsdóttir vd., 2015 \\
\hline & Tarım alanları & Agricultural areas & Greenleaf vd., 2014 \\
\hline & Banliyöler & Suburban areas & Greenleaf vd., 2014 \\
\hline \multirow{11}{*}{$\begin{array}{l}\text { Kent } \\
\text { İçi }\end{array}$} & Yeşil alanlar & Green spaces & Brazier, 2017; Reese \& Lewis, 2019 \\
\hline & Kamusal alanlar & Public spaces & Summers \& Vivian, 2018 \\
\hline & Kent meydanları & Urban squares & Juan vd., 2017 \\
\hline & Üniversite kampüsleri & University campuses & Juan vd., 2017 \\
\hline & Caddeler & Streets & Kusmane vd., 2019 \\
\hline & Kent ormanları & Urban forests & Pedersen vd., 2019; Wilson vd., 2009 \\
\hline & $\begin{array}{l}\text { Botanik bahçeleri ve } \\
\text { arboretumlar }\end{array}$ & Botanical gardens/arboretas & Schebella vd., 2017 \\
\hline & Parklar & Parks & $\begin{array}{l}\text { Barnes vd., 2019; Burls, 2007; Ibes vd., 2018; Jordan } \\
\text { \& Marshall, 2010; Juan vd., 2017; Pálsdóttir vd., 2015, } \\
\text { Pasanen vd., 2018; Pedersen vd., 2019; Reese \& } \\
\text { Lewis, 2019; Sackett, 2010; Schebella vd., 2017; } \\
\text { Wilson vd., 2009; Wolsko \& Hoyt, } 2012\end{array}$ \\
\hline & Özel yeșil alanlar & Private green spaces & Schebella vd., 2017 \\
\hline & Avlular & Yards & Kusmane vd, 2019 \\
\hline & Bahçeler & Gardens & $\begin{array}{l}\text { Burls, 2007; Clatworthy vd., 2013; Pálsdóttir vd., 2015, } \\
\text { Stoltz \& Schaffer, 2018; Summers \& Vivian, } 2018\end{array}$ \\
\hline
\end{tabular}

çeperinde yer alan terapötik alanlar ise çiftlikler, çok fonksiyonlu tarım alanları, tarım alanları ve banliyöler olarak tariflenmiştir (Tablo 3).

Çalışma kapsamında, kentsel alanların içerisinde doğal alanlarla etkileşimin günlük yaşamın bir parçası haline getirilmesinin önemi sebebiyle kent içerisinde yer alan terapötik alan türleri ayrıca önem arz etmektedir. $\mathrm{Bu}$ alanlar ise mülkiyetleri temelinde kamusal ve özel olarak ikiye ayrılmaktadır. Kamusal terapötik çevreler yeşil alanlar, kamusal alanlar, kent meydanları, üniversite kampüsleri, caddeler, kent ormanları, botanik bahçeleri ve arboretumlar ve parklar olarak gruplanmıştır (Tablo 3). Yapılan inceleme sonucunda parkların sıklıkla bahsedildiği ve türlere ayrıldığı görülmektedir. Bahsi geçen park türleri ise kent parklar1 (Juan vd., 2017; Pasanen vd., 2018; Reese \& Lewis, 2019; Sackett, 2010; Wilson vd., 2009), küçük cep parkları (Burls, 2007), spor parkları, doğa parkları, lineer parklar, kıyı parkları, toplum parkları ve okul parkları (Summers \& Vivian, 2018) olarak detaylanmaktadır. Özel mülkiyetteki kent içi terapötik çevrelerin ise özel yeșil alanlar, avlular ve bahçeler olarak belirtildiği, bahçelerin ise yenebilir orman bahçeleri (Stoltz \& Schaffer, 2018) ve sağllk bahçeleri (Pálsdóttir vd., 2015) olarak detaylandırıldığ

Terapötik çevrelerin türlerinin belirlenmesi, kentsel tasarım sürecinde kent dışında, çeperinde ve kent içerisinde konumlanan bu alanların kentleşme baskısına karşı korunmasına yönelik yaklaşımlar gerektirmesi sebebiyle önem arz etmektedir. Nüfus artışı gibi itkilerle büyümeye eğilimli olan kentin ve hatta özellikle değişim ve dönüşüm bakımından son derece dinamik olan ve kent ile ilişkili sorunların yoğunlaştığı büyük kentlerin, başta tartışıldığı üzere doğal çevre üzerinde olumsuz etkilere sebep olacak biçimde gelişmesinin önüne geçil- 
mesi, ek olarak kentlinin sağlığı açısından arz ettikleri önem doğrultusunda terapötik doğal ve yeșil alanların erișilebilirliklerinin sağlanması, tasarım ve planlama yaklaşımlarında, kentleşme stratejilerinde ve kentsel politikaların üretiminde göz önünde bulundurulmalıdır. Son olarak teknik ve sosyal altyapının sağlanmasında daha avantajlı olan kentsel gelişim alanları planlanır ve tasarlanırken bu alanların mümkün olduğunca fazla miktarda ve çeşitlilikte sağlanabilmesi için türlerinin bilinmesinde yarar vardır. Kent içerisinde yayılan kamusal fonksiyonlar, meydanlar, caddeler, özel mülkiyetteki alanlar gibi alanların potansiyelleri değerlendirildiğinde yalnızca yeşil alanlarla sınırlı kalmayan bu yaklaşımın, kent dokusunun tüm bileşenleriyle terapi hizmeti verebilecek nitelikte tasarlanmasına katkısı olacaktır. Kentsel tasarım sürecinde kamusal alanların kentteki dağılımı ve türleri, caddelerin kesitleri ve cadde peyzajı, yerleşim alanlarındaki yapılaşma tipi ve mesafeleri bu bakış açısıyla değerlendirilebilir. Yeşil alanlar özelinde bakıldığında ise kentlilerin terapi hizmeti alabilecekleri türde terapötik yeşil alanların sağlanması, mevcut yeşil alanların bu yaklaşımla yeniden değerlendirilerek dönüştürülmesi ve bu alanların kentin içerisinde ihtiyaca yönelik olarak çeşitlendirilmesi bakımından terapötik çevrelerin türlerinin bilinmesi önemlidir.

\subsection{Ekoterapötik Çevrelerin Özellikleri}

Ekoterapötik ortamların yararları ve türlerinin yanı sıra, bu ortamların ekopsikoloji ve restorasyon çalışmalarında tanımlanmış özellikleri de incelenmiştir. Bu amaçla ça- lışmalarda terapötik veya restoratif olarak tanımlanan alanların mekânsal özellikleri tespit edilmiş ve bu özellikler erișilebilirlik, boyut, tasarım ilkeleri, içerdikleri donatılar, doğal peyzaj elemanları, fauna ve yarattıkları hisler şeklinde gruplanmıştır (Sekil 4).

İncelenen çalışmaların çoğunda yeşil alanların erişilebilirliğinin önemine, yeşil alanların günlük yaşamın bir parçası haline getirilmesi bağlamında değinilmiştir. Ancak iki çalışma erişilebilirliği doğrudan mekânsal niteliklerle açıklamaktadır. Burls (2007) tarafindan konutlar ve yeşil alanlar arasındaki ideal mesafe 300 metre olarak tanımlanırken, Greenleaf ve diğerleri (2014) tarafından ise yaşanılan konuttan itibaren 1 $\mathrm{km}$ yarıçaplık mesafe içerisinde yeşil alanların bulunması gerektiği vurgulanmaktadır. Dolayısıyla yeşil alan kullanımının günlük yaşamın bir parçası haline getirilebilmesi için yaşam alanlarına yürüme mesafesinde konumlanmalarının gerektiği görülmektedir.

Terapötik doğal alanların ideal büyüklüğü ise sadece iki çalışmada tanımlanmaktadır. Bagot ve diğerleri (2015) genel olarak bu alanların büyük tasarlanmasının yararlı olacağından bahsederken, Burls (2007) ideal yeşil alanı 1000 kişi başına 2 ha (kişi başına $20 \mathrm{~m}^{2}$ ) olarak tanımlamıştır. Kişi başına düşen asgari yeşil alan büyüklüğü, yerel yasal planlama düzenlemesi olan 'Mekânsal Planlar Yapım Yönetmeliğinde' de $10 \mathrm{~m}^{2}$ olarak tanımlanmaktadır. Bununla birlikte, yeşil alanın büyüklüğünün tek başına anlamlı bir özellik olmadığı; doğa, işlev, kullanıcı ihtiyaçları ve yeşil alanın

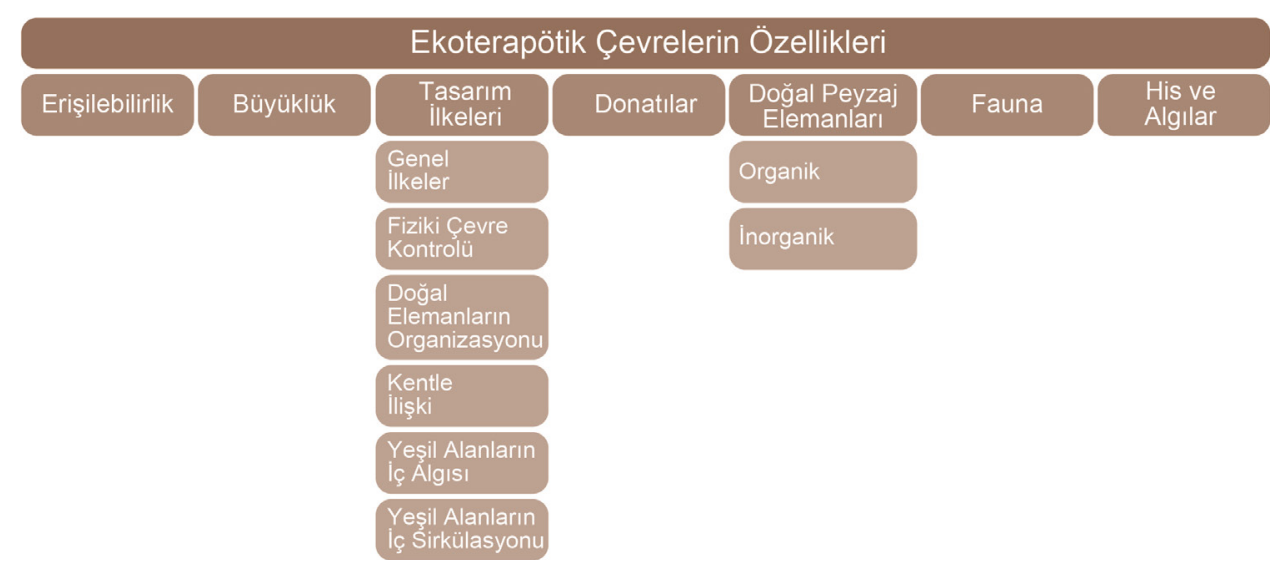


Tablo: 4

Ekoterapötik feurelerin tasarım ilkeleri. konumu gibi diğer özelliklere bağlı olarak anlam kazanan bir özellik olduğu değerlendirilmelidir.

Tasarım ilkeleri, ekopsikoloji ve restoratif çevre çalışmalarında ekoterapötik çevrelere dair en sık bahsedilen özellikler olmaları nedeniyle niteliklerine göre kendi içinde alt gruplara ayrılmıştır. Bu gruplardan ilki biyomorfik tasarım, sanatsal tasarım, mimari kalite, yüksek mimari çeşitlilik, de- taylı cepheler, kültürel / tarihi, rekreatif ve panoramik özellikler ve kimlik gibi genel tasarım yaklaşımları ve sağlanması gereken özelliklerdir (Tablo 4). İkinci grup, yeşil alanda kontrol edilmesi gereken gün ışığı, temiz hava ve rüzgâr esintisi miktarını ve dengesini kapsayan fiziksel çevre kontrolü konularını içermektedir (Tablo 4). Üçüncü grup doğal elemanların düzenlemesi ile ilgilidir ve doğal elemanların varlığı, düzeni, çeşitliliği ve yoğunluğu gibi konuları

\begin{tabular}{|c|c|c|c|c|}
\hline & & Özellikler & Orijinal Adı & Kaynak \\
\hline & & Biyomorfik tasarım & Biomorphic design & Abdelaal \& Soebarto, 2019 \\
\hline & & Sanatsal tasarım & Artistic design & Scopelliti vd., 2019 \\
\hline & $\stackrel{\omega}{\Phi}$ & Mimari kalite & Architectural quality & Scopelliti vd., 2019 \\
\hline & $\stackrel{\text { 兰 }}{\bar{\alpha}}$ & Mimari çeşitlilik & Architectural variation & Lindal \& Hartig, 2013 \\
\hline & $\stackrel{\oplus}{\leftrightarrows}$ & Detaylı cepheler & Detailed facades & Lindal \& Hartig, 2013 \\
\hline & ஸँ & $\begin{array}{l}\text { Kültürel/tarihi, rekreatif ve } \\
\text { panaromik özellikler }\end{array}$ & $\begin{array}{l}\text { Cultural/historical, recreational and } \\
\text { panaromic features }\end{array}$ & San Juan vd., 2017 \\
\hline & & Kimlik & Identity & Bornioli vd., 2018 \\
\hline & 픈ㄹㄴ응 & Gün ışığı & Day light/light & $\begin{array}{l}\text { Abdelaal \& Soebarto, 2019; Ibes vd., } \\
2018\end{array}$ \\
\hline & 준 & Temiz hava & Fresh air & Ibes vd., 2018 \\
\hline & & Rüzgar & Wind breeze & Abdelaal \& Soebarto, 2019 \\
\hline & & Doğal elemanların varlığı & Natural elements & Bagot vd., 2015 \\
\hline & & Doğal elemanların düzeni & Natural settings & Abdelaal \& Soebarto, 2019 \\
\hline & $\frac{\overline{0}}{\mathrm{C}}$ & Doğal elemanların çeşitliliği & Diversity of natural elements & Juan vd., 2017 \\
\hline & है के & Dogal elemanların yogunluğu & Density of natural elements & Juan vd., 2017 \\
\hline & $\frac{1}{11} \stackrel{N}{=}$ & Bitki türleri & Vegetation types & Pasanen vd., 2018 \\
\hline & एक बٓ & Bitki çeşitliliği & Vegetation diversity & Stoltz \& Schaffer, 2018 \\
\hline & 8 & Bitki yoğunluğu & Vegetation density & Hauru vd., 2012; Reese \& Lewis, 2019 \\
\hline & & Bitki hacmi & Vegetation volume & Bagot vd., 2015 \\
\hline & & $\begin{array}{l}\text { Yeşil alanın kentten } \\
\text { görünürlüğünün artıııması }\end{array}$ & Visibility from residences/window view & $\begin{array}{l}\text { Hartig vd., 2003; Stoltz \& Schaffer, } \\
2018\end{array}$ \\
\hline Tasarım & & $\begin{array}{l}\text { Yeşil alandan kentin } \\
\text { görünürlüğünün azaltıması }\end{array}$ & $\begin{array}{l}\text { Not to see urban layout/increased } \\
\text { distance from urban matrix }\end{array}$ & Hauru vd., 2012 \\
\hline Ilkeleri & $\frac{\bar{x}}{\underline{\omega}_{n}}$ & $\begin{array}{l}\text { Yeşil alanın etrafındaki kentsel } \\
\text { yoğunluğun düşürülmesi }\end{array}$ & Low urban density & Barnes vd., 2019 \\
\hline & 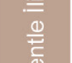 & $\begin{array}{l}\text { Yeşil alanın etrafındaki kat } \\
\text { yüksekliklerinin düşürülmesi }\end{array}$ & Lower building heihgts & Lindal \& Hartig, 2013 \\
\hline & $\stackrel{\oplus}{\Perp}$ & $\begin{array}{l}\text { Yeşil alandan kente yumuşak bir } \\
\text { geçiş sağlanması }\end{array}$ & $\begin{array}{l}\text { Mild transection from park to urban } \\
\text { pattern }\end{array}$ & Hauru vd., 2012 \\
\hline & & $\begin{array}{l}\text { Yeşil alanın içinde ana yollardan } \\
\text { uzakta, doğa içinde olma } \\
\text { algısının yüksek olduğu alanların } \\
\text { tasarlanması }\end{array}$ & Speration from main paths & Ibes vd., 2018 \\
\hline & & $\begin{array}{l}\text { Uzaktaki manzaraların } \\
\text { görünürlüğü }\end{array}$ & Remote landscapes & Reese \& Lewis, 2019 \\
\hline & $\overline{\underline{\Phi}}$ & $\begin{array}{l}\text { Görsel derinliğin orta seviyede } \\
\text { kurgulanmas }\end{array}$ & Moderate depth & Wilson vd., 2009 \\
\hline & $\begin{array}{l}\overline{5} \\
\text { ư } \\
\text { un }\end{array}$ & $\begin{array}{l}\text { Karmaşıklığın orta seviyede } \\
\text { kurgulanması }\end{array}$ & Moderate complexity & Wilson vd., 2009 \\
\hline & 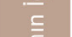 & Odak noktaların yaratılması & Presence of focal points & Wilson vd., 2009 \\
\hline & $\frac{\overline{0}}{4}$ & Dengeli bir kapalılık yaratıması & Balanced enclosure & Stoltz \& Schaffer, 2018 \\
\hline & \& & Dengeli bir yoğunluk yaratıması & Balanced density & Stoltz \& Schaffer, 2018 \\
\hline & & $\begin{array}{l}\text { Geniş ve açık manzaraların } \\
\text { sağlanması }\end{array}$ & More prospect and less refuge views & Juan vd., 2017; Hauru vd., 2012 \\
\hline & & $\begin{array}{l}\text { Doğal, vahşi ve eldeğmemiş bir } \\
\text { görüntü sağlanması }\end{array}$ & Natural, wildlike and intact view & Stoltz \& Schaffer, 2018; Burls, 2007 \\
\hline & 등 & Hareketin kolaylaştırılması & Easy movement & Wilson vd., 2010 \\
\hline & $\frac{0}{\frac{0}{3}}$ & Yön bulmanın kolaylaştırılması & Easiness of orientation & Wilson vd., 2010 \\
\hline & 立 & Geçirgen bir mekan yaratılması & Passableness & Wilson vd., 2010 \\
\hline
\end{tabular}


içermektedir (Tablo 4). Çalışmalar özellikle yeșil alandaki bitki türlerinin, çeșitliliğini ve önemini göstermektedir (Tablo 4). Ancak çalışmalar bu özelliklerin önemini yalnızca işaret etmekte, ideal özelliklere dair bir ölçüt tanımlamamaktadır. Dördüncü grup yeşil alanlar ile çevreleyen kentsel alan arasındaki görsel ve mekânsal ilişkilerdir. $\mathrm{Bu}$ grup, yerleşim alanlarından yeşil alanın görünürlügünü artırmak, parkların etrafındaki kentsel yoğunluğun ve kat yüksekliklerinin düşürülmesiyle kentsel alanın parktan görünürlüğünü azaltmak ve parktan kente doğru dereceli ve yumuşak bir geçiş sağlamak gibi çift yönlü görsel tasarım ilkelerini içermektedir (Tablo 4). Ek olarak, Ibes ve diğerleri (2018) daha 'doğa içinde (in-nature)' algısı yaratan bir ortamın sağlanması için ana yollardan ayrılmış alanlar tasarlamayı önermektedir. Beşinci grup terapötik çevrelerin içerisindeki görsel/ algısal özelliklerle ilgili ilkeleri içermektedir. Bu ilkeler, mevcut ise uzakta yer alan manzaraların görünmesine izin verilmesi, görsel derinliğin ve karmaşıklığın orta seviyede kurgulanması, odak noktalarının yaratılması, dengeli bir kapalılık ve yoğunluk yaratılması, kapalılığı daha az, geniş ve açık manzaraların sağlanması ve son olarak doğal, vahşi ve el değmemiş gibi görünen bir bitki örtüsünün sağlanmasıdır (Tablo 4). Son grup ise alan içerisindeki hareketliliği konu almakta, içerisinde hareketin ve yön bulmanın kolay olduğu, geçirgen bir çevre yaratılması gerektiğinden bahsetmektedir (Wilson vd., 2010) (Tablo 4).

Terapötik çevrelerin ele alınan bir diğer özelliği olan donatılar, tasarlanan alanın tema, konum, kullanıcı profili vb. özellikleri nedeniyle çeşitlenebilmektedir. Çoğunlukla kullanıcı ihtiyaçları veya estetik amaçlarla inşa edilen donatıların ve malzemelerinin önemi, incelenen çalışmalardan üçünde tanımlamıştır. Bunlar mobilya ve döşeme malzemelerinin doğallığı (Bagot vd., 2015; Schebella vd., 2017); ahşap ve taş işleri (Abdelaal \& Soebarto, 2019); parkurlar, egzersiz ekipmanları ve yüzme havuzları gibi sportif elemanlar; sanat eserleri ve genel anlamda bu donatıların bakımı (Schebella $v d ., 2017$ ) gibi konulardır (Tablo 5). Yapılan değerlendirmelere bakıldığında donatıların malzemelerine ve bakımına ve özellikle sportif aktiviteleri arttırıcı donatılara ağırlık verildiği görülmektedir. Dolayısıyla, alanın temasına ve kullanıcı ihtiyaçlarına göre şekillenmesi gereken donatı türlerinin tanımlanması yerine, sağlanacak donatıların alanın doğal niteliklerine uygun malzemelerle inşa edilmesi, bakımlarının yapılması ve insanları daha aktif olmaya ve doğada egzersiz yapmaya yönlendirecek ekipmanların sağlanması gerektiği yorumu yapılabilir.

Terapötik çevrelerin bir başka bileşeni olan doğal peyzaj elemanları çeşitlerine göre organik ve inorganik olmak üzere iki gruba ayrılmaktadır. Organik peyzaj elemanları çoğunlukla bitki örtüsünün varlığı ile ilgilidir. Bazı çalışmalar organik peyzaj elemanlarını genel olarak bitki örtüsü, bitkilendirme, flora, peyzaj, sokak peyzaj1, yeşil alanlar ve bahçeler olarak olarak tanımlarken; bazıları ise detaylandırarak doğal ağaçlık alanlar, ağaçlar, büyük yaşlı ağaçlar, cadde ağaçları, çalılar, çim yüzeyler ve çiçekler olarak tanımlamaktadır (Tablo 5). İnorganik doğal peyzaj elemanları ise, terapötik alanlardaki su elemanlarının ve inorganik manzaraların varlığı ve görünürlüğü ile ilgilidir. Bazı çalışmalar suyu genel olarak sadece mavi alanların, suyun, su elemanlarının varlığı olarak değerlendirmekte, bazıları ise dere, akarsu ve göl gibi daha spesifik su elemanları tanımlamaktadır (Tablo 5). Son olarak, inorganik manzaralar ise terapötik alanların içinde var olan veya uzağında yer alarak bu alanlardan izlenebilen mineralleri, kayalıkları ve yamaçları kapsamaktadır (Tablo 5).

Terapötik çevrelerin bir diğer bileşeni bu alanlarda yer alan faunadır. İncelenen çalışmalardan sekizi terapötik çevrelerdeki fauna varlığından, vahşi yaşamdan, kuşlardan ve kuşları duymanın öneminden bahsetmektedir (Tablo 5). Biyoçeşitliliğin içkin değerinin yanı sıra, terapötik çevrelerde yaban hayvanları ile karşılaşmak, insan dışında var olan farklı yaşam formlarını gözlemlemek ve hatırlamak anlamında önemlidir. Pek çok ekoterapi yönteminde de yardımcı olarak kullanılan hayvanlar ile karşılaşmak, bu alanlardan alınacak 
Tablo: 5

Ekoterapötik feurelerde yer alan donatılar, doğal peyzaj elemanları, fauna ve ekoterapötik mekânların yarattı̆̆ı his ve algılar. olan terapi hizmetinin artışında da etkili olacaktır.

Son olarak, ekopsikoloji ve restorasyon çalışmaları terapötik ortamların yaratması gereken hislere ve algılara değinmektedir. Bunlar sessizlik, sukunet, uzak olma hissi, güzellik, estetik, çekicilik, kişisel bağlantı, gizem, güvenlik ve çeşitlilik olarak belirtilmiştir (Tablo 5).

Sonuç olarak, terapi hizmeti veren mekanların özelliklerinin belirlenmesi, kentsel alanların planlanması ve tasarımı sürecinde bu hizmeti vermeye elverişli mekanların tasarlanabilmesi açısından önemlidir.

Tanımlanan özellikler içerisinden kentsel tasarım sürecinde değerlendirilmesi bakımından öne çıkan konulardan ilki, kentsel yeşil alanlar temelinde ele alındığında bu alanların günlük hayatın bir parçası olarak kullanıldığı mekânlar haline gelebilmeleri için kişilerin yaşama/çalışma mekânlarına olabildiğince yakın ve yürüme mesafesinde tasarlanması gerektiğidir. Alanların büyüklüğü için ise net bir tanımlama yapılmamış olmakla birlikte, olabildiğince

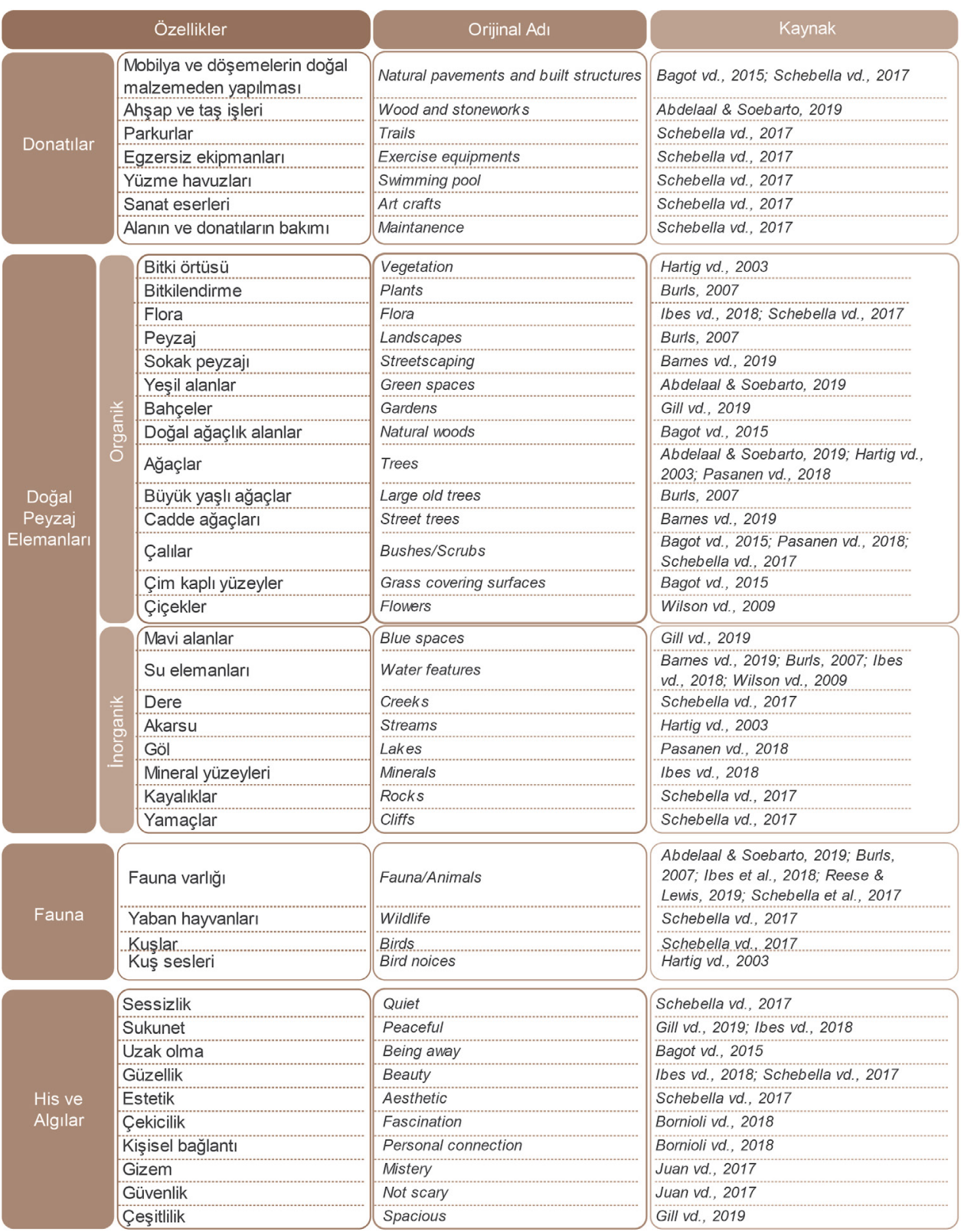


büyük alanların yaratılması kişiye sağladığı yararlarının yanında, ekosistemlerin bölünmemesi anlamında da önemlidir. Dolayısıyla mekânsal tasarım süreçlerinde yalnızca noktasal olarak değil, bir sistem olarak sürekli ve kentsel dokunun içine sızan yeşil alanların tasarlanması gerek erişilebilirliğin, gerekse yeterli büyüklük ve ekosistem devamlılığının sağlanabilmesi açısından yararlı olacaktır.

Tasarım ilkelerinde öne çıkan konuların çoğunluğunun kentsel yeşil alanlar ile ilişkili olduğu görülmekte olup bunlardan ilki alanların çeşitlilik ve estetik öğeler içeren, kimlikli alanlar olarak tasarlanması gereğidir. Bunun yanında diğer konu başlıklarının tümünde doğal öğelerin ağırlı̆̆ göze çarpmaktadır. Bu öğelerin varlığı, yoğunluğu ve mekân içerisinde manzara ve odak noktaları oluşturacak şekilde organize edilmesinin önemi işaret edilmiş; kapalılık-açıklık dengesinin iyi kurgulanması ve olabildiğince doğal görünümlü peyzajların yaratılması gerektiği vurgulanmıştır. Bununla ilgili, özellikle çevreleyen mekânın potansiyellerinin (manzara vb.) iyi değerlendirildiği, bitkilendirmenin ise yalnızca estetik kaygilarla değil bu potansiyellerin ortaya çıkarılacağı ve parkın içerisinde farklı algılara sahip mekânların çeşitleneceği şekilde yapıldığı tasarım yaklaşımları benimsenebilir. Bu yaklaşım doğal görünümlü peyzajların sağlanması bakımından ise gerek bitkilendirmenin organizasyonu, gerekse bitki türlerinin seçimi ve bak1mında göz önünde bulundurulmalıdır. İç özelliklerinin yanında kentle kurduğu görsel ilişki anlamında da değerlendirilen alanların kent içerisinden olabildiğince görünür olması gerektiği, alanların içinden ise kent siluetinin görülmemesinin daha olumlu olduğunun altı çizilmiştir. Ek olarak bahsedilen yeşil alandan kente doğru dereceli olarak yoğunlaşan kent dokusu ve artan kat sayıları bu alanların kentin iç kesimlerinden de görünürlüğünü artıracak, aynı zamanda alanların içinden kent siluetinin görünürlüğünü azaltacaktır. Yeşil alan içerisinden kentin görünürlüğünün azaltılması ise parktaki sirkülasyon hatları ve aktivite noktalarından kent görünürlüğü analizlerinin yapılması ve bitkilendirme ve diğer peyzaj düzenlemelerinin görsel bir engel oluşturacak şekilde tasarlanmasıyla mümkün olacaktır.

Tasarım sürecine katkıda bulunabilecek bir başka konu tasarım ilkeleri grubunda da ağırlığı fazla olan doğal peyzaj elemanlarıdır. Kent içerisindeki yeşil alanların yanı sıra caddeler ve bahçeler gibi alanları da kapsayan bu hususta kent içerisinde ve yeşil alanlarda yaratılan peyzajın terapi hizmeti sağlar nitelikte olabileceğinden bahsedilmiştir. Bu etkiyi artırmak amacıyla kullanılabilecek elemanlardan bitkilerin ve su elemanlarının öne çıktığı görülmektedir. Su elemanlarının önemi doğrultusunda kent topoğrafyasında yer alan su toplama hatları ve mevcut deniz kıyısı, akarsu, göl ve sulak alanların korunduğu ve yeşil altyapıya entegre edildiği tasarım yaklaşımları göz önünde bulundurulabilir. Benzer şekilde kent dokusu ve cadde kesitleri, doğal peyzaj elemanlarının yer alabileceği ön bahçeli veya ayrık nizam yapılaşma veya bitkilerin yer aldığı cadde kesitleri şeklinde tasarlanabilir.

Bir başka grup olan yeşil alan donatıları konusunda belirli bir donatı türü tanımlanmadığı, donatıların malzemelerine ve sağlayacakları aktivitelerin çeşitliliğine ağırlık verildiği görülmektedir. Bu hususta alanın niteliklerine uygun, olabildiğince doğal malzemeden yapılmış donatı, mobilya ve döşemelerin kullanılması; alan içerisinde tasarlanacak donatı alanı ve ekipmanlarla fiziksel aktivitenin teşvik edilmesi gibi öneriler öne çıkmaktadır. Bu doğrultuda dayanıklılık ve maliyet kaygılarının yanında estetik ve çevreye uygunluk da donatı tipi ve malzemesinin seçiminde önemli birer kriter haline gelmektedir. Benzer şekilde alan içerisinde yapılacak aktivitelerin çeşitlenmesi de çoğunlukla sağlanan tesisler ile mümkün olduğundan olabildiğince çeşitli donatının bu alanlarda yer alması gerekmektedir.

Çalışmalarda bahsi geçen diğer bir konu kent dokusunun ve yeşil alanların yaban hayatını barındırması ve insanla fauna arasındaki etkileşimdir. Bu hususta kentte kalıcı veya dönemsel olarak yaşayan faunanın korunması bakımından, hem 
kentsel dokunun hem de yeşil alanların tasarlanması sürecinde faunanın dikkatli bir biçimde analiz edilmesi ve daha önce de bahsedildiği gibi kentteki faunaya büyük ölçüde ev sahipliği yapan yeșil ve mavi altyapının mevcut ekosistemlerin bölünmediği ve zarar görmediği biçimde tasarlanması gerekmektedir.

Son olarak kentsel yeşil alanların terapi hizmeti verirken yarattığı hisler ve algılar değerlendirildiğinde çoğunlukla sakinlik ve karmaşadan uzak algıların ağır bastığı görülmektedir. Bu anlamda yeşil alanlarda veya kentsel dokunun genelinde mekânın yanısıra kullanıcıların mekânı deneyimleme biçimlerinin tasarlanması gerektiğinden bahsedilebilir. Dolayısıyla tasarım sürecinde farklı deneyimlerin kurgulanabilmesi ve karmaşadan uzak deneyimlerin sağlanabilmesi için kentle kurulan görsel ilişkide olduğu gibi, kent kaynaklı görüntü ve ses kirliliğinin engellendiği ve yeşil alan içerisinde varsa sükûneti bozan fonksiyonların mekânsal olarak farklı alanlarda çözülerek veya ayırıcı nitelikte tasarlanan bitkiler ve topoğrafya ile ayrılarak etki alanının azaltıldığı tasarım yaklaşımları benimsenebilir.

\subsection{Terapötik Aktiviteler}

Ekoterapi, bir psikiyatri uzmanından veya doğanın kendisinden etkileşimle ve içerisinde bulunarak alınabilen bir hizmettir. 'Doğada olmak', ekopsikoloji ve restorasyon çalışmalarında doğada çalışmak ve doğayı deneyimlemek olmak üzere iki farklı şekilde ele alınmaktadır (Şekil 5). Çalışmalarda belirlenen terapi hizmetinin alınması için yapılacak aktiviteler, diğer bir deyişle terapötik aktiviteler, bu iki ana başlık altında gruplandırılmıştır.

Doğada çalışma grubu altında öncelikle genel olarak spor, egzersiz, yeşil egzersiz, mavi egzersiz gibi aktivitelerden bahsedilmektedir (Tablo 6). Ayrıca bazı çalışmaların spesifik olarak bahsettiği faaliyetler türlerine göre spor, terapi/meditasyon, sanatsal faaliyetler ve doğada/doğayla üretim olmak üzere gruplandırılmıştır. Ekoterapi hizmeti almak için doğada yapılabilecek sporlar kayıkçılık, balık tutma, kano, yüzme, doğa gezisi, kamp, dağ gezisi, bisiklet sürme, dağ bisikleti sürme, binicilik, koşu, jogging, trekking ve yürüyüş olarak tanımlanmıştır (Tablo 6). Terapi ve meditasyon aktiviteleri arasında macera terapisi, hayvan destekli terapi, sanat terapisi, hareket yoluyla vücut terapisi, bahçecilik terapisi, vahşi yaşam terapisi, orman meditasyonu, su kenarında meditasyon ve doğa güdümlü farkındalık/meditasyon çalışmaları bulunmaktadır (Tablo 6). Bu faaliyetler bireysel olarak öğrenilip uygulanabileceği gibi, terapistler ile de gerçekleştirilebilir. Doğada gerçekleştirilecek sanat faaliyetlerinin ise her türlü sanat faaliyetini kapsayabileceği belirtilmiş; çevre sanatı (environmental art) ve doğa ve sanatın entegrasyonu gibi örnekler verilmiştir (Tablo 6). Doğada çalışmanın son grubu olan doğada/doğayla üretim ise peyzaj aktiviteleri, bahçecilik, tarım, yerel çevre iyileştirme aktiviteleri, vahşi yaşam koruması, dış mekânda çalışma ve dış mekânda eğitim gibi aktiviteleri içermektedir (Tablo 6). Doğayı deneyimleme ise gözlem, kuş gözlemciliği, kuş sesi dinleme, dinlenme ve oturma, sosyal aktiviteler, piknik ve okuma gibi aktiviteleri içermektedir (Tablo 7).

Görüldüğü üzere, ekoterapi hizmetinin alınması amacıyla doğada yapılabilecek birçok faaliyet tanımlanmıştır. Bu faaliyetlerin bir kısmı kent içinde yer alan alanlarda yapılması güç olan aktiviteler olmasına karşın, pek çoğu kent içerisinde ve kentsel
Şekil: 5

Terapötik aktiviteler. 


\begin{tabular}{|c|c|c|}
\hline & & Aktiviteler \\
\hline \multirow{37}{*}{$\begin{array}{l}\text { Doğada } \\
\text { Çalışma }\end{array}$} & \multirow{4}{*}{ 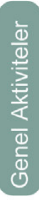 } & Spor \\
\hline & & Egzersiz \\
\hline & & Yeşil egzersiz \\
\hline & & Mavi egzersiz \\
\hline & \multirow{14}{*}{ के } & Kayıkçılık \\
\hline & & Balık tutma \\
\hline & & Kano \\
\hline & & Yüzme \\
\hline & & Doğa gezisi \\
\hline & & Kamp \\
\hline & & Dağ gezisi \\
\hline & & Bisiklet sürme \\
\hline & & Dağ bisikleti \\
\hline & & Binicilik \\
\hline & & Koşu \\
\hline & & Jogging \\
\hline & & Trekking \\
\hline & & Yürüyüş \\
\hline & \multirow{9}{*}{ 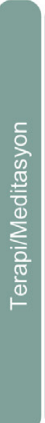 } & Macera terapisi \\
\hline & & Hayvan destekli terapi \\
\hline & & Sanat terapisi \\
\hline & & Hareket yoluyla vücut terapisi \\
\hline & & Bahçecilik terapisi \\
\hline & & Vahşi yaşam terapisi \\
\hline & & Orman meditasyonu \\
\hline & & Su kenarında meditasyon \\
\hline & & $\begin{array}{l}\text { Doğa güdümlü } \\
\text { farkındalı//meditasyon }\end{array}$ \\
\hline & \multirow{3}{*}{$\begin{array}{l}\frac{\pi}{\mathbb{\pi}} \\
\frac{\mathbb{D}}{\infty}\end{array}$} & Her türlü sanat faalieyti \\
\hline & & Çevre sanatı \\
\hline & & Doğa ve sanatın entegrasyonu \\
\hline & \multirow{7}{*}{ 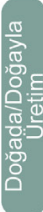 } & Peyzaj aktiviteleri \\
\hline & & Bahçecilik ve bahçivanlik \\
\hline & & Tarım \\
\hline & & Yerel çevre iyileştirme aktiviteler \\
\hline & & Vahşi yaşam koruması \\
\hline & & Diş mekanda çalışma \\
\hline & & Dış mekanda eğitim \\
\hline
\end{tabular}

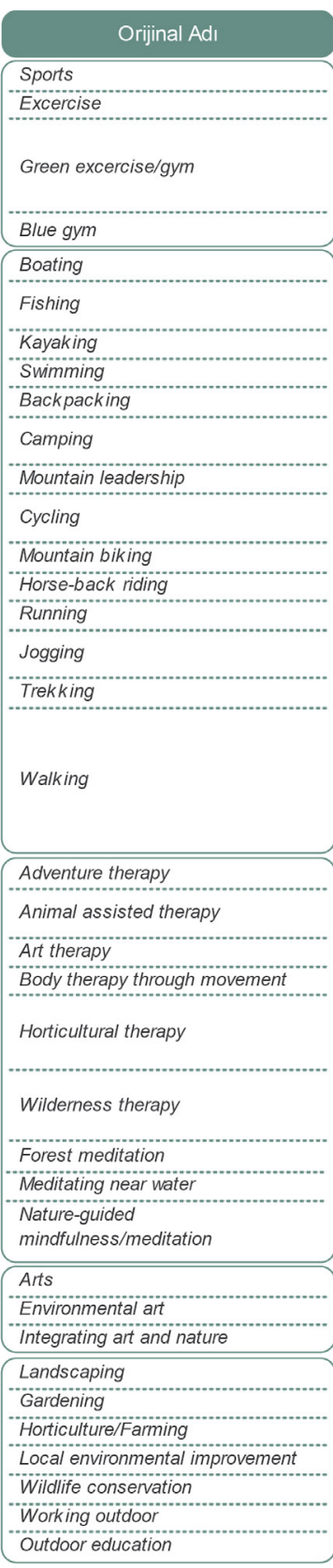

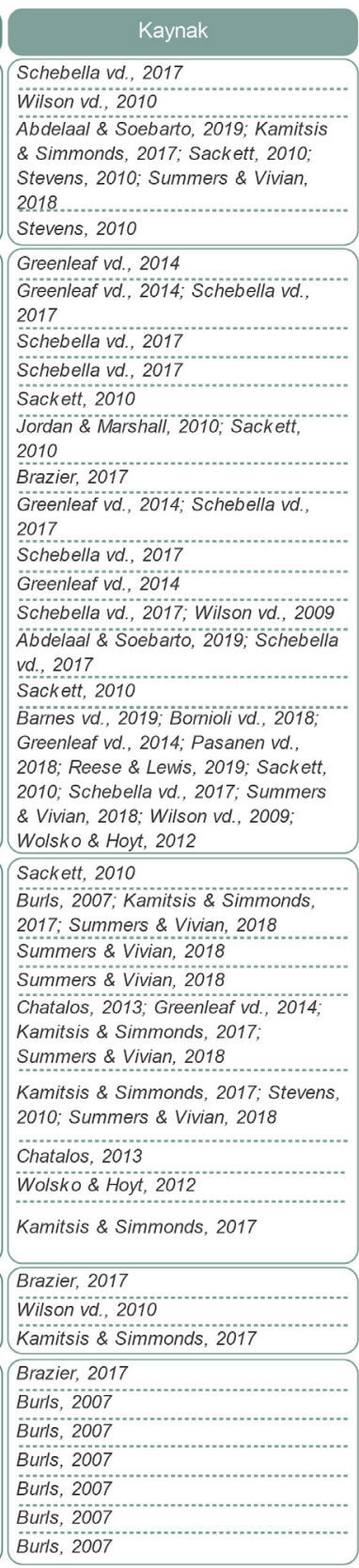

fonksiyonların kent içerisindeki konumu ve erişim mesafesine, hem de kat edilecek mesafenin çevresel niteliklerine bağlıdır. Dolayısıyla bu faaliyetler, gerek en üst ölçekten başlayacak ulaşım ve kentsel fonksiyon dağılımlarının kararı aşamasında, gerekse yürünebilir çevrelerin ve yeşil alanlar içerisinde gerçekleştirilecek aktiviteler için elverişli mekân ve donat1ların sağlanması amacıyla kentsel tasarım sürecinde değerlendirilmelidir. Mevzubahis aktivitelere elverişli bir kentsel doku ve
Tablo: 6

Doğada çalışarak yapılan ekoterapötik aktiviteler. yeşil alanlarda günlük olarak yapılabilecek niteliktedir. Özellikle yürüyüş ve gözlem gibi aktivitelerin literatürdeki yoğunluğuna bakıldığında, öncelikle kent içerisinde kurgulanacak yaya sirkülasyonunun niteliği ve doğal alan ve elemanlarla ilişkisi önem kazanmaktadır. Kentlinin kent içerisinde bir yerden bir yere ulaşmak amacıyla yürümeyi veya aktif ulaşım seçeneklerini tercih etmesini teşvik edecek bir kentsel sirkülasyonun tasarlanması, hem kentsel 
Tablo: 7

Doğayı deneyimlemek için yapılan ekoterapötik aktiviteler.

\begin{tabular}{|c|c|c|c|}
\hline & Aktiviteler & Orijinal Adi & Kaynak \\
\hline \multirow{8}{*}{$\begin{array}{c}\text { Doğayı } \\
\text { Deneyimlemek }\end{array}$} & Gözlem & Observing/Viewing & $\begin{array}{l}\text { Abdelaal \& Soebarto, 2019; Burls, } \\
2007 \text {; Kamitsis \& Simmonds, 2017; } \\
\text { Pasanen vd., 2018; Summers \& } \\
\text { Vivian, 2018) }\end{array}$ \\
\hline & Kuş gözlemciliği & Bird watching & Schebella vd., 2017 \\
\hline & Kuş sesi dinleme & Bird noice listening & Abdelaal \& Soebarto, 2019 \\
\hline & Dinlenme & Leisure activities & Brazier, 2017 \\
\hline & Oturma & Sitting & Barnes vd., 2019; Schebella vd., 2017 \\
\hline & Sosyal aktiviteler & Social events & Brazier, 2017 \\
\hline & Piknik & Picnics/Dining & Schebella vd., 2017 \\
\hline & Okuma & Reading & Schebella vd, 2017 \\
\hline
\end{tabular}

yeşil alan sistemi ile en başta bahsedilen kentlinin kentsel mekânın elverişsiz olması sebebiyle pasifize olduğu bir yaşam tarzı ve buna bağlı olarak ortaya çıkan sağlık sorunlarının çözülmesi kaçınılmaz olacaktır.

\section{Sonuç}

Öngörülen küresel ve kentsel nüfus artışı, kentleşmeyi gerek çevresel sorunlar, gerekse kentlerdeki yaşam kalitesi ve insan sağlığı bağlamında, günümüz ve gelecek için irdelenmesi gereken bir olgu haline getirmektedir. Kentleşmenin ve çevresel sorunların kaynağı ve aynı zamanda etkileneni olan insanın ise sağlığı, psikolojisi ve içerisinde var olduğu ekosisteme karşı bilinci, kentleşme ve benzeri pek çok beşeri faaliyetin etkileri konusunda belirleyicidir. Bu bakımdan bireylerin kentsel alanda doğadan uzaklaşması sonucu ortaya çıkan insanın psikolojik krizi ve çevresel kriz arasındaki ilişkiyi inceleyen ekopsikoloji (Rozsak, 1992) yaklaşımı, ekoterapiyi bireyin dönüşümü üzerinden bu sorunlara bir çözüm önerisi olarak sunmaktadır. Barındırdıkları nüfus ve beşeri aktivitelerin yoğunluğu ve doğadan kopuşun derinleştiği alanlar olarak kentler, bu dönüşümün gerçekleşmesi gereken başlıca alanlardır. $\mathrm{Bu}$ dönüşüm için ise kentlerin ekoterapi hizmetine elverişli olması gerektiği görülmektedir. Bu çalışmada, insanın doğayla yeniden ilişki kurmasına yardımcı olan ekoterapi hizmetinin sağlandığı mekânların özelliklerinin anlaşılması amacıyla terapötik alanların faydaları, türleri, özellikleri ve bu hizmetin sağlanması için yapılabilecek aktiviteler incelenmiş; tüm bunların kentsel tasarım sürecine hangi adımda nasıl katkı sağlayabileceği tartışılmıştır.

Ekoterapötik mekânların sağladığı faydalara bakıldığında çalışmanın giriş kısmında tartışılan kent kaynaklı sağlık sorunlarının pek çoğuna çözüm getirdiği görülmektedir. Bu bağlamda terapötik alanlardan sağlanan faydalarının anlaşılması, gerek kent ölçeğinde gerekse yeşil alanlar özelinde verilecek mekânsal kararların, kentlinin sağlığı ve çevre bilinci üzerindeki etkisinin anlaşılması adına önemlidir. Çünkü bu faydalar gözetilerek verilen mekansal kararlar ile hem kent kaynaklı sağlık sorunlarının hem de çevre sorunlarının çözülebileceği görülmektedir.

Ekoterapötik alanların türleri değerlendirildiğinde, çalışmanın giriş bölümünde bahsedildiği üzere, kentleşme ve beşeri faaliyetlerin etkisiyle çevresel sorunların görüldüğü alanların terapötik alanlar ile örtüştüğü görülmektedir. Dolayısıyla hem çevresel sorunların ve kentleşme baskısının bu alanlar üzerindeki etkilerinin azaltılması için, hem de bu etkilerin azaltılmasında önemli role sahip olan 'bireysel dönüşümün' gerçekleşeceği mekânlar olmaları sebebiyle; planlama ve tasarım süreçlerinin tüm aşama ve ölçeklerinde mevcut terapötik mekânların korunması ve eksik olan bölgelerde sağlanmasına yönelik kararların verilmesi gerekmektedir.

Terapötik alanların özellikleri incelendiğinde, doğal öğelerin önem kazandığı; bitkiler ve bitki düzenlemeleri, hayvan varlığı, mavi altyapının yeşil altyapıya entegrasyonu gibi konuların öne çıktığı görülmektedir. Benzer şekilde bu özelliklerin bilinmesi, kent içerisinde terapi hizmeti sunan mekanların sağlanması için ağırlık verilmesi gereken fonksiyonlar, elemanlar ve bu fonksiyon ve elemanların organizasyonlarına dair kriterler sunmaktadır. Bu kriterlerin ise planlama ve tasarım disiplinlerine, kent bütününe ilişkin üst ölçekli 
kararlardan, park veya caddelerde kullanılacak donatıların malzemelerine kadar geniş bir ölçek ve yelpazede katkı sunduğu görülmektedir.

Terapötik aktiviteler değerlendirildiğinde ise en başında kentsel alan içerisinde hem doğal alanlardan hem de aktif bir yaşam tarzından uzak kalan kentlinin, kent içerisinde aktif bir hayat sürmesine yönelik faaliyetler tanımlandığı görülmektedir. Tanımlanan faaliyetlerin çeşitliliği sebebiyle, yeşil alanlar özelinde çeşitli donatıların sunulduğu ve ek olarak kent içerisinde günlük hayatta ihtiyaç duyulan aktif ulaşım alternatiflerine elverişli bir doku ve sirkülasyon tasarlandığı durumda, bu aktivitelerin pek çoğu kentsel alanda yapılabilir hale gelmektedir. Bu faaliyetler gözetilerek yapılan kentsel tasarım ve planlama uygulamalarının ise kentliyi daha aktif bir yaşam biçimine teşvik edebileceği söylenebilir. Dolayısıyla bu husus, ulaşım planlamasından, spor alanı veya yürüyüş kulvarı tasarımı gibi detaylara kadar çeşitlenen ölçekler arası bir yaklaşım gerektirmesi sebebiyle, planlama ve kentsel tasarım disiplinlerinin çeşitli ölçek ve aşamalarına katk1 sunabilmektedir.

Sonuç olarak, mekânı şekillendirmede önemli bir araç olan planlama ve kentsel tasarım disiplinlerinde ekopsikoloji yaklaşımının araştırılması, terapötik niteliklerin ve nasıl sağlanacağının bilinmesi, hem doğal ve kentsel alanların ele alınışına, hem de kentin ve kentlinin sorunlarının çözümüne yeni bir bakış açısı getirmesi sebebiyle değerlidir. Aynı zamanda incelenen literatür, kentleşme biçimine ve kentsel mekana yapılacak müdahalelerle hem çevresel sorunlara hem de bireyin kentte yaşadığı sorunlara çözüm getirilebileceğini göstermektedir. İncelenen pek çok çalışmada kentsel sorunlara değinilirken, çevre bilimlerine bu perspektifin de değerlendirilmesi gerektiğine dair atıfta bulunulduğu görülmektedir. İncelenen ekopsikoloji ve ekoterapi çalışmaları, bağlı oldukları disiplinin konusu ve yöntemleri gereği psikolojik bir araştırmanın özelliklerine sahiptir. Ancak insanın çevresi ve psikolojisi arasındaki kuvvetli ilişki doğrultusunda çevre bilimleri için de önemli bir çalışma alanı haline gelmesi sebebiyle, mekânın nitelikleri ve tasarımı ile ekoterapi hizmeti arasındaki ilişkiyi inceleyecek mekânsal araştırmaların yapılmasına, hem çevresel ve kentsel sorunların çözümü, hem de kamu yararının gözetilmesi hususunda kentlinin bedensel ve zihinsel sağlığının iyileştirilmesi için ihtiyaç olduğu görülmektedir•

274 Sayı 3ı, Kasım 2020 


\section{Kaynakça}

Abdelaal, M. S., \& Soebarto, V. (2019). Biophilia and Salutogenesis as restorative design approaches in healthcare architecture. Architectural Science Review, 62(3), 195-205. https://doi.org/10.1080/00 038628.2019 .1604313

Arthur, M., Liu, G., Hao, Y., Zhang, L., Liang, S., Asamoah, E. F., \& Lombardi, G. V. (2019). Urban food-energy-water nexus indicators: A review. Resources, Conservation and Recycling, 151(February), 104481. https://doi.org/10.1016/j. resconrec.2019.104481

Bagot, K. L., Allen, F. C. L., \& Toukhsati, S. (2015). Perceived restorativeness of children's school playground environments: Nature, playground features and play period experiences. Journal of Environmental Psychology, 41, 1-9. https://oi. org/10.1016/j.jenvp.2014.11.005

Barnes, M. R., Donahue, M. L., Keeler, B. L., Shorb, C. M., Mohtadi, T. Z., \& Shelby, L. J. (2019). Characterizing nature and participant experience in studies of nature exposure for positive mental health: An integrative review. Frontiers in Psychology, 9(JAN), 1-8. https://doi.org/10.3389/ fpsyg.2018.02617

Beatley, T. (2011). Biophilic cities: Integrating nature into urban design and planning. Washington, DC: Island Press.

Bhugra, D., Castaldelli-Maia, J. M., Torales, J., \& Ventriglio, A. (2019). Megacities, migration, and mental health. The Lancet Psychiatry, 6(11), 884-885. https://doi.org/10.1016/ S2215-0366(19)30294-9

Bornioli, A., Parkhurst, G., \& Morgan, P. L. (2018). The psychological wellbeing benefits of place engagement during walking in urban environments: A qualitative photo-elicitation study. Health and Place, 53(March), 228-236. https://doi. org/10.1016/j.healthplace.2018.08.018

Brazier, C. (2017). Ecotherapy in Practice. In Ecotherapy in Practice. https://doi.org/10.4324/9781315208268

Burls, A. (2007). People and green spaces: promoting public health and mental well-being through ecotherapy Ambra. Journal of Public Mental Health, 6(3), 24-29.

Chamie, J. (2020). World Population: 2020 Overview. https://yaleglobal.yale.edu/content/ world-population-2020-overview

Chatalos, P. A. (2013). Nachhaltigkeit: Öko-psychologische Einsichten und personzentrierte Beiträge. PersonCentered and Experiential Psychotherapies, 12(4), 355-367. https://doi.org/10.1080/14779757. 2013.855136

Clatworthy, J., Hinds, J., \& Camic, P. M. (2013). Gardening as a mental health intervention: A review. Mental Health Review Journal, 18(4), 214-225. https:/ doi.org/10.1108/MHRJ-02-2013-0007

Clinebell, H. (1996). Ecotherapy: healing ourselves.

Cole, D. N., \& Hall, T. E. (2010). Experiencing the restorative components of wilderness environments: Does congestion interfere and does length of exposure matter? Environment and Behavior, 42(6), 806-823. https://doi. org $/ 10.1177 / 0013916509347248$

Davis, K. M., \& Atkins, S. S. (2009). Ecotherapy: Tribalism in the mountains and forest. Journal of Creativity in Mental Health, 4(3), 273-282. https://doi. org/10.1080/15401380903192747
Williams, C., Eri, R., Brook, B. W., \& Buettel, J. C. (2019). Urban-associated diseases: Candidate diseases, environmental risk factors, and a path forward. Environment International, 133(September), 105187. https://doi.org/10.1016/j. envint.2019.105187

Gill, C., Packer, J., \& Ballantyne, R. (2019). Spiritual retreats as a restorative destination: Design factors facilitating restorative outcomes. Annals of Tourism Research, 79(June), 102761. https:// doi.org/10.1016/j.annals.2019.102761

Grassini, S., Revonsuo, A., Castellotti, S., Petrizzo, I., Benedetti, V., \& Koivisto, M. (2019). Processing of natural scenery is associated with lower attentional and cognitive load compared with urban ones. Journal of Environmental Psychology, 62, 1-11. https://doi.org/10.1016/j.jenvp.2019.01.007

Greenleaf, A. T., Bryant, R. M., \& Pollock, J. B. (2014). Nature-Based Counseling: Integrating the Healing Benefits of Nature Into Practice. International Journal for the Advancement of Counselling, 36(2), 162-174. https://doi. org/10.1007/s10447-013-9198-4

Hartig, T., Evans, G. W., Jamner, L. D., Davis, D. S., \& Gärling, T. (2003). Tracking restoration in natural and urban field settings. Journal of Environmental Psychology, 23(2), 109-123. https://doi. org/10.1016/S0272-4944(02)00109-3

Hauru, K., Lehvävirta, S., Korpela, K., \& Kotze, D. J. (2012). Closure of view to the urban matrix has positive effects on perceived restorativeness in urban forests in Helsinki, Finland. Landscape and Urban Planning, 107(4), 361-369. https://doi. org/10.1016/j.landurbplan.2012.07.002

Ibes, D., Hirama, I., \& Schuyler, C. (2018). Greenspace ecotherapy interventions: The stress-reduction potential of green micro-breaks integrating nature connection and mind-body skills. Ecopsychology, 10(3), 137-150. https://doi.org/10.1089/ eco.2018.0024

Ichimura, M. (2003). Urbanization, urban environment and land Use: Challenges and opportunities an issue paper, Asia-Pacific Forum for Environment and Development Experting Meeting, Guilin, China.

Jackson, L. E. (2003). The relationship of urban design to human health and condition. Landscape and Urban Planning, 64(4), 191-200. https://doi. org/10.1016/S0169-2046(02)00230-X

Jordan, M., \& Marshall, H. (2010). Taking counselling and psychotherapy outside: Destruction or enrichment of the therapeutic frame? European Journal of Psychotherapy and Counselling, 12(4), 345-359. https://doi.org/10.1080/13642537.2010.530105

Juan, C. S., Subiza-Pérez, M., \& Vozmediano, L. (2017). Restoration and the city: The role of public urban squares. Frontiers in Psychology, 8(DEC), 1-13. https://doi.org/10.3389/fpsyg.2017.02093

Jung, C. G. (1999). Keşfedilmemiş Benlik. İlhan Yayınevi.

Kamitsis, I., \& Simmonds, J. G. (2017). Using Resources of Nature in the Counselling Room: Qualitative Research into Ecotherapy Practice. International Journal for the Advancement of Counselling, 39(3), 229-248. https://doi.org/10.1007/ s10447-017-9294-y

Kellert, S. (2014). Biophilia and biomimicry: evlutionary adaptation of human versus nonhuman nature, Intelligent Buildings International, 8:2, 51-56, DO I:10.1080/17508975.2014.902802

Kindel, P. J. (2019). Biomorphic urbanism: A guide for

Flies, E. J., Mavoa, S., Zosky, G. R., Mantzioris, E., 
sustainable cities. https://medium.com/@SOM/ biomorphic-urbanism-a-guide-for-sustainable-cities-4a1da72ad656.

Kumar, P., Druckman, A., Gallagher, J., Gatersleben, B., Allison, S., Eisenman, T. S., Hoang, U., Hama, S., Tiwari, A., Sharma, A., Abhijith, K. V., Adlakha, D., McNabola, A., Astell-Burt, T., Feng, X., Skeldon, A. C., de Lusignan, S., \& Morawska, L. (2019). The nexus between air pollution, green infrastructure and human health. Environment International, 133(June), 105181. https://doi. org/10.1016/j.envint.2019.105181

Kusmane, A. S., Ile, U., \& Ziemelniece, A. (2019). Importance of trees with low-growing branches and shrubs in perception of urban spaces. IOP Conference Series: Materials Science and Engineering, 471(9). https://doi.org/10.1088/1757899X/471/9/09206

Lindal, P. J., \& Hartig, T. (2013). Architectural variation, building height, and the restorative quality of urban residential streetscapes. Journal of Environmental Psychology, 33, 26-36. https://doi. org/10.1016/j.jenvp.2012.09.003

Liu, L., Zhong, Y., Ao, S., \& Wu, H. (2019). Exploring the relevance of green space and epidemic diseases based on panel data in China from 2007 to 2016. International Journal of Environmental Research and Public Health, 16(14). https://doi.org/10.3390/ ijerph16142551

Moore, M., Gould, P., \& Keary, B. S. (2003). Global urbanization and impact on health. International Journal of Hygiene and Environmental Health, 206(4-5), 269-278. https://doi. org/10.1078/1438-4639-00223

Mutatkar, R. K. (1995). Public health problems of urbanization. Social Science and Medicine, 41(7), 977-981. https://doi.org/10.1016/0277-9536(94)00398-D

Pálsdóttir, A. M., Wissler, S. K., Nilsson, K., Petersson, I. F., \& Grahn, P. (2015). Nature-based rehabilitation in peri-urban areas for people with stress-related Illnesses -A controlled prospective study. Acta Horticulturae, 1093, 31-35. https:// doi.org/10.17660/ActaHortic.2015.1093.2

Pasanen, T., Johnson, K., Lee, K., \& Korpela, K. (2018). Can nature walks with psychological tasks improve mood, self-reported restoration, and sustained attention? Results from two experimental field studies. Frontiers in Psychology, 9(OCT), 1-22. https://doi.org/10.3389/fpsyg.2018.02057

Pedersen, E., Weisner, S. E. B., \& Johansson, M. (2019). Wetland areas' direct contributions to residents' well-being entitle them to high cultural ecosystem values. Science of the Total Environment, 646, 1315-1326. https://doi.org/10.1016/j. scitotenv.2018.07.236

Pedersen Zari, M. (2010). Regenerative design for the future. BUILD, Vol. 115, January 2010, 68-69.

Pedretti-Burls, A. (2007). Ecotherapy: a therapeutic and educative model. Journal of Mediterranean Ecology, 8, 19-25.

Phelps, C., Butler, C., Cousins, A., \& Hughes, C. (2015). Sowing the seeds or failing to blossom? A feasibility study of a simple ecotherapy-based intervention in women affected by breast cancer. Ecancermedicalscience, 9, 1-9. https://doi. org/10.3332/ecancer.2015.602

Phillips, D. R. (1993). Urbanization and human health. Parasitology, 106(S1), S93-S107. https://doi. org/10.1017/S0031182000086145
Qiu, Y., Liu, Y., Liu, Y., \& Li, Z. (2019). Exploring the linkage between the neighborhood environment and mental health in Guangzhou, China. International Journal of Environmental Research and Public Health, 16(17). https://doi.org/10.3390/ ijerph16173206

Reed, B. (2007). Forum: Shifting from "sustainability" to regeneration. Building Research and Information, 35(6), 674-680. https://doi. org/10.1080/09613210701475753

Reese, R. F., \& Lewis, T. F. (2019). Greening counseling: examining multivariate relationships between ecowellness and holistic wellness. Journal of Humanistic Counseling, 58(1), 53-67. https://doi. org/10.1002/johc. 12089

Reichert, M., Braun, U., Lautenbach, S., Zipf, A., EbnerPriemer, U., Tost, H., \& Meyer-Lindenberg, A. (2020). Studying the impact of built environments on human mental health in everyday life: methodological developments, state-of-the-art and technological frontiers. Current Opinion in Psychology, 32, 158-164. https://doi.org/10.1016/j. copsyc.2019.08.026

Restivo, V., Cernigliaro, A., \& Casuccio, A. (2019). Urban sprawl and health outcome associations in sicily. International Journal of Environmental Research and Public Health, 16(8), 1-9. https://doi. org/10.3390/ijerph16081350

Rozsak, T. (1992). The Voice of Earth: An Exploration of Ecopsychology. Simon \& Schuster.

Sackett, C. R. (2010). Ecotherapy: A counter to society's unhealthy trend? Journal of Creativity in Mental Health, 5(2), 134-141. https://doi.org/10.1080/1540 1383.2010 .485082

Schebella, M. F., Weber, D., Lindsey, K., \& Daniels, C. B. (2017). For the love of nature: exploring the $1 \mathrm{~m}-$ portance of species diversity and micro-variables associated with favorite outdoor places. Frontiers in Psychology, 8(DEC). https://doi.org/10.3389/ fpsyg.2017.02094

Scopelliti, M., Carrus, G., \& Bonaiuto, M. (2019). Is it really nature that restores people? A comparison with historical sites with high restorative potential. Frontiers in Psychology, 9(JAN), 1-12. https://doi.org/10.3389/fpsyg.2018.02742

Scull, J. (2008). Ecopsychology: Where does it fit in psychology in 2009? The Trumpeter, 24(3), 68-85.

Singh, R. L. (2017). Introduction to Environmental Biotechnology. In Principles and Applications of Environmental Biotechnology for a Sustainable Future (pp. 1-12). Springer. http://www.springer. com/series $/ 13085$

Steg, L., van den Berg, A. E., \& de Groot, J. I. M. (2012). Environmental Psychology : An Introduction. John Wiley \& Sons, Incorporated. http:// ebookcentral.proquest.com/lib/itup/detail. action?docID $=888149$

Stevens, P. (2010). Embedment in the environment: A new paradigm for well-being? Perspectives in Public Health, 130(6), 265-269. https://doi. org/10.1177/1757913910384047

Stoltz, J., \& Schaffer, C. (2018). Salutogenic affordances and sustainability: Multiple benefits with edible forest gardens in urban green spaces. Frontiers in Psychology, 9(DEC). https://doi.org/10.3389/ fpsyg.2018.02344

Summers, J. K., \& Vivian, D. N. (2018). Ecotherapy - A forgotten ecosystem service: A review. Frontiers in Psychology, 9(AUG), 1-13. https://doi. 
org/10.3389/fpsyg.2018.01389

Szczygiel, B. (2003). "City beautiful” revisited: An analysis of nineteenth-century civic improvement efforts. Journal of Urban History, 29(2), 107-132. https:// doi.org/10.1177/0096144202238870

T.C. Resmi Gazete. Mekansal Planlar Yapım Yönetmeliği. 14.6.2014. Sayı:29030, Başbakanlık Basımevi, Ankara

Ulrich, R. S. (1983). Aesthetic and affective response to natural environment. Behavior and the Natural Environment, 85-125. https://doi. org/10.1007/978-1-4613-3539-9 4

Wang, D., \& MacMillan, T. (2013). The benefits of gardening for older adults: A systematic review of the literature. Activities, Adaptation and Aging, 37(2), 153-181. https://doi.org/10.1080/01924788. 2013.784942

Weimann, A., \& Oni, T. (2019). A systematised review of the health impact of urban informal settlements and implications for upgrading interventions in South Africa, a rapidly urbanising middle-income country. International Journal of Environmental Research and Public Health, 16(19), 1-17. https:// doi.org/10.3390/ijerph16193608

Wheeling, S. D. (1993). Making sense. The West Virginia Medical Journal, 89(3), 113.

Wilson, N., Fleming, S., Jones, R., Lafferty, K., Cathrine, K., Seaman, P., \& Knifton, L. (2010). Green shoots of recovery: the impact of a mental health ecotherapy programme. Mental Health Review Journal, 15(2), 4-14. https://doi.org/10.5042/ mhrj.2010.0366

Wilson, N., Ross, M., Lafferty, K., \& Jones, R. (2009). A review of ecotherapy as an adjunct form of treatment for those who use mental health services. Journal of Public Mental Health, 7(3), 23-35.

Wolsko, C., \& Hoyt, K. (2012). Employing the restorative capacity of nature: Pathways to practicing ecotherapy among mental health professionals. Ecopsychology, 4(1), 10-24. https://doi. org/10.1089/eco.2012.0002 